\title{
Synthesizing Sustainability Considerations through Educational Interventions
}

\author{
Maaike Mulder-Nijkamp ${ }^{1,2, *}$, Bjorn de Koeijer ${ }^{1,2}$ and Robbert-Jan Torn ${ }^{2}$ \\ 1 TIFN Food \& Nutrition, P.O. Box 557, 6700 AN Wageningen, The Netherlands; b.l.a.dekoeijer@utwente.nl \\ 2 Department of Design, Production and Management, Faculty of Engineering Technology, \\ University of Twente, Drienerlolaan 5, 7522 NB Enschede, The Netherlands; i.a.r.torn@utwente.nl \\ * Correspondence: m.mulder-nijkamp@utwente.nl
}

Received: 15 November 2018; Accepted: 2 December 2018; Published: 20 December 2018

\begin{abstract}
This study addresses the synthesis of sustainability-related considerations in packaging design curricula by means of educational interventions. The core of the research revolves around an educational module for students in packaging design and development. This research targets the current late-stage integration of sustainability considerations in product-packaging development processes. The combination of the front-end involvement of sustainability considerations with the focus on educational interventions in product-packaging development is lacking in currently available research. The educational interventions which are tested in representative educational environments-as presented in this article-address the required focus on the balance in decisions and criteria, trade-offs, and team dynamics within multidisciplinary product-packaging development teams. The educational framework targets five perspectives of packaging sustainability: (1) managerial decision making, (2) life cycle assessment (LCA), (3) consumer purchase behavior, (4) recycling efficiency and effectiveness, and (5) plastic recycling chain redesign. This research's main contribution is bridging the gap between implementing new scientific insights in the field of sustainable packaging from various perspectives, and practicing by applying the relevant knowledge in this field, by means of a design synthesis approach. This research derives findings from both an extensive introspective analysis and expert analysis of the results of the educational module.
\end{abstract}

Keywords: packaging design; packaging development; design brief, teaching; education; sustainable development; development team; team dynamics; design synthesis

\section{Introduction}

As the urgency of tackling climate change continues to grow, sustainability remains a hot topic. In recent years, the concept of sustainability has developed from a theoretical definition provided by the well-known Brundtland report [1], to becoming a worldwide known and applied approach to increasing awareness of environmental impact at the economic, social, and environmental levels [2]. In various decision-making processes-within academia, policy making, business organizations, and NGOs-the focus on the integration of considerations related to sustainable development is expanding. Currently, in decision-making processes, these considerations mainly take place at the strategic level rather than the operational level. The field of sustainability is still developing in this direction; therefore, we can speak of a misalignment between the strategic and the operational levels [3]. In the field of packaging, sustainability is also high on the agenda. The awareness of impacts with respect to the environmental burden of product-packaging chains is increasing and there is an intense pressure to act urgently on the challenge of packaging waste. Across Europe, new laws and policies are being proposed to tackle this problem, from plastic bottle deposit systems [4] to phasing out non-recyclable packaging [5]. Such measures are being developed to prevent the environmental burden imposed 
by existing packaging. However, if we really want to address this problematic development, we need to tackle the roots of the problem, focusing on developing more sustainable product-packaging combinations. We speak of product-packaging combinations, because the packaging is in the service of the product within the complete supply chain and provides more than just the function of protecting the content, but also informing about and transporting the product [6-9].

In current product-packaging development processes, sustainability considerations are mainly tackled at the end of the design process, implementing minor changes in the product design, that lead to only negligible effects on the environmental burden. This approach is known as eco-efficiency [10]. However, recent years have shown an increased interest in continuous material cycles, in which materials can be recycled without loss of quality, like Cradle to Cradle [11,12] and the concept of the circular economy [10]. These approaches can be explained as eco-effectiveness.

Incorporation of sustainability considerations in an early stage of the product development process will be crucial to create more eco-effective product-packaging solutions. Furthermore, when implementing sustainability at an early stage, the early-stage environmental lock-in is key [3]. In other words: the probability of creating more eco-effective sustainable product-packaging combinations will be higher when we start thinking about sustainability immediately from the start of the design process, by selecting more sustainable effective measures. Incorporating sustainability at an early stage of the design process supports both existing and future designers in such a way that they regard sustainability as equally important as other disciplines such as technical constraints and marketing. Analyzing this challenge, we encountered two main problems that need to be discussed.

Currently, the integration of new scientific insights in packaging development processes regarding sustainability-related design choices remains limited, due to the inadequate applicability of theoretical knowledge in design processes [3,13-15]. During the product development process, sustainability considerations mainly play a relevant role at a strategic level. The impact of sustainability considerations at an operational level seems to be limited because of the cost, time to market, and technical challenges [3]. The misalignment between the strategic and operational levels is a serious problem and needs to be overcome.

The second problem we intend to address is the lack of integration among scientific insights from various perspectives of sustainability in the education field of young packaging designers. The inclusion of sustainability in education is a crucial step to stimulate the dialogue with this theme in practice. These novice designers are the packaging managers and directors of the future, and need to become aware of the fact that sustainability is an increasingly relevant part of the design process, which also relates to technical and societal constraints. However, in the current curricula development of higher education, sustainability is not always integrated in the design process in a more holistic approach $[16,17]$. In most cases, only one perspective regarding sustainability is implemented, and that is merely based on the traditional, science-oriented approach involving tools and methods [17]. There are knowledge-based books addressing specific topics of sustainability such as LCA or consumer behavior towards sustainability $[18,19]$. However, the delivery of courses that focus on a more integrative approach remains limited. Nevertheless, the structured implementation of sustainability considerations in the packaging design processes requires design teams to possess relevant and applicable knowledge on this implementation, especially focusing on the integration of dilemmas encountering during the design process [3,20-22]. The success of sustainable packaging development relies on both technological development and social considerations $[18,22]$ and requires insights from all perspectives covering the complete life cycle of a product-packaging combination. During the process, novice packaging designers need to encounter and practice by applying various perspectives regarding sustainability, learning to make balanced decisions (trade-offs) to finally arrive at the best synthesis.

In this paper, we aim to bridge the gap between implementing new scientific insights in the field of sustainable packaging from various perspectives, and practicing by applying the relevant knowledge in this field. To simulate the complex interaction of various perspectives, an educational module is 
developed and integrated in a course of 15 ECTS taken by packaging students of Industrial Design Engineering at the University of Applied Sciences in The Hague (The Netherlands). The setup of this educational module is based on five perspectives of sustainability [23] and aims to integrate both scientific and practice-based knowledge to design more sustainable product-packaging combinations. This paper will further elaborate on both the efficacy and effectiveness of this educational module, describing the results of an extensive introspective analysis and an expert analysis of the results of the course.

The innovative approach of the educational module is the integrative aspect of the subject sustainability addressing five perspectives, with the dilemmas that often occur during such processes. Designers needs to deal with various kinds of information, such as technical-oriented information (e.g., recyclable materials, technical specifications, technical constraints about the end of life) and societally-oriented information (consumer purchase and recycling behavior regarding sustainability). These insights converge in a real-life packaging design case, using a serious gaming concept during an early stage of the design process that acts as a synthesis tool. This educational module promotes an integrative approach focusing on learning about the environmental consequences of various fields involved in packaging sustainability.

The holistic approach of the course and the tools that are offered support students in making more balanced choices to finally design a product-packaging combination that leads to synthesis of all disciplines. The term design synthesis is an important contemplation and will be explained in the next chapter.

\section{Design Synthesis}

The key characteristic of the educational module is the alignment of semi-related knowledge bases into one integrated entity. These knowledge perspectives cover one topic (packaging sustainability), but address these from various perspectives, ranging from behavioral considerations and managerial decision making to material-related analysis and recycling effectiveness. In order to achieve this integration and to improve the efficacy of the module as an educational intervention, we scope the development within design research. More specifically, design synthesis-following analysis-focused research steps [24-27] — is what shapes the added value of design research for the development of the integrated educational module. The notion that research that focuses on "merely" analytical reasoning will not result in the full integrated inclusion of knowledge bases into one multi-perspective educational module directs this research's synthesis focus. Design synthesis enables the educational module to provide more added value in transferring knowledge than separate knowledge bases would, as shown in Figure 1. Furthermore, the integrative nature of the educational module enables the students to follow this design synthesis approach in their development process, and to include the combined knowledge bases as a synthesized foundation for product-packaging development.

Within the educational module, the identification and recognition of trade-offs is key. When combining the various perspectives on sustainability in packaging design, the relevance, depth, and applicability of the perspectives can be ambiguous. As a result, the balance in focus and emphasis can vary, resulting in inevitable trade-offs during the design process in which the knowledge must be integrated. In literature on sustainability in development processes, the relevance of balancing trade-offs is well-established-both within and beyond the scope of product-packaging development (e.g., Byggeth \& Hochschorner (2006) [13], De Koeijer (2017) [3], Deutz et al. (2013) [28], Wever \& Vogtländer (2014) [29]). Therefore, this poses a critical point within an educational module targeting sustainability-related knowledge in product-packaging development processes. For the didactic value of the educational module, tools targeting balanced trade-offs are essential.

The combination of the described synthesis-focused research towards (1) the integration of novel sustainability-related knowledge in product-packaging development education, and (2) the requirement for balancing trade-offs direct the development of educational interventions. The first intervention is a project guidance tool in the form of a design game to simulate stakeholder 
interrelations and decision-making in product-packaging development processes. The dashed line in Figure 1 represents the design game which acts as synthesis tool to manifest trade-off balancing between the major areas in the product development process. The second intervention is a real-life packaging design case in which the newly acquired packaging sustainability knowledge must be incorporated. Together, these interventions shape the design synthesis of the educational module. In the following sections, the setup of the educational module, and the development and application of these interventions are addressed.
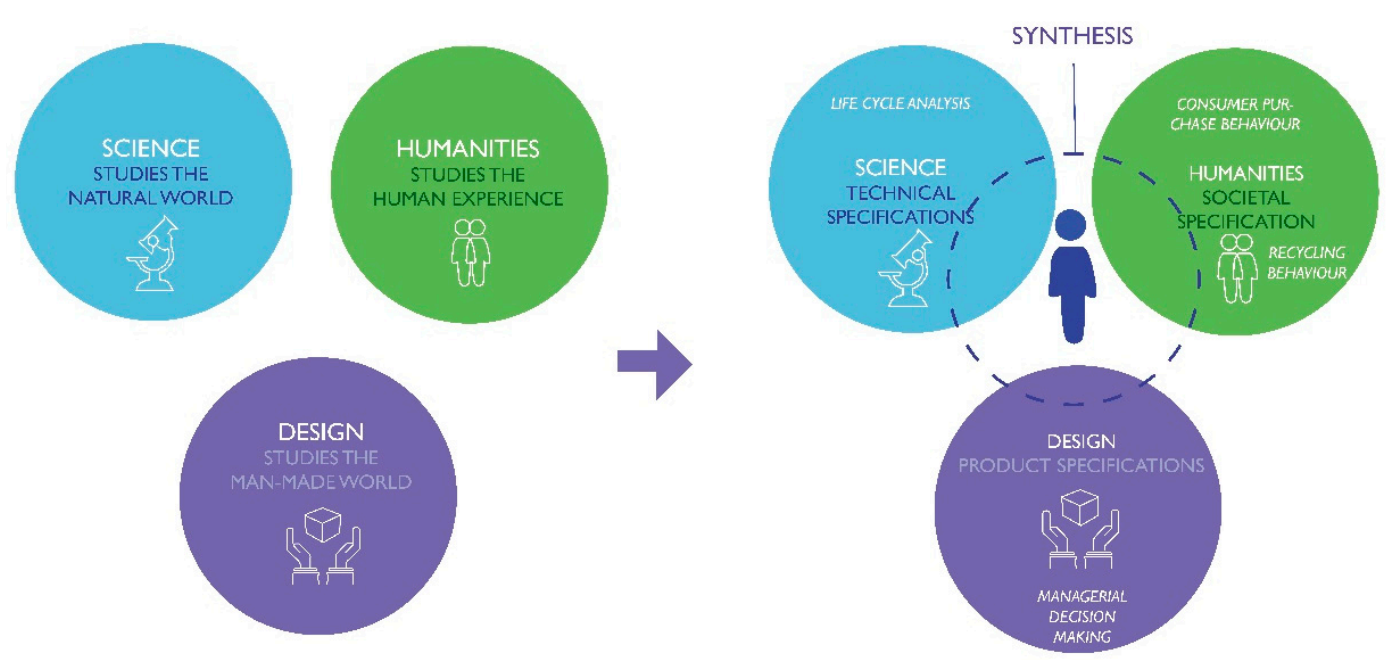

Figure 1. The research's synthesis focus for the integration of knowledge bases.

\section{Educational Module}

This educational module builds upon insights developed in a four-year scientific research program initiated by the Netherlands Institute for Sustainable Packaging (KIDV) and the Dutch Top Institute Food and Nutrition (TIFN) to reduce the environmental burden caused by product-packaging chains in the Netherlands. The insights can be divided into five perspectives on product-packaging sustainability: (1) managerial decision making, to understand the various decision-making roles and trade-offs between development-influencing factors in sustainable product-packaging development processes; (2) life cycle assessment (LCA), measuring the tangible sustainability scores of new product-packaging designs; (3) consumer purchase behavior, addressing the perceived sustainability of product-packaging designs; (4) recycling efficiency and effectiveness, focusing on the recycling behavior of consumers, in response to packaging design factors; and (5) plastic recycling chain redesign, aiming to further align product-packaging designs with current plastic recycling chains and processes. In the research program, several universities and institutes are cooperating, based on their research expertise in relation to these perspectives. The selection of these perspectives was based on a range of stakeholder perspectives (including designers, marketers, consumers, and recyclers) to simulate a real-life situation, and the consideration of various sections of the product-packaging chain. This integrated approach towards considering the product-packaging chain as a whole, and the various stakeholders within this chain, is a relevant addition to the currently available research [30-32].

The main focus of the educational module is the alignment and integration of the insights derived from the research program with the students' baseline packaging design knowledge. This alignment between theory and practice is implemented by (1) the involvement in teaching of the experts and researchers who collected and developed these insights; (2) the application of a real-life packaging design project as the common ground of development; and (3) a synthesis tool in the form of a serious game to integrate all perspectives to help designers in becoming aware of the critical decisions in the development process. The latter will support the design students during the synthesis of complex considerations in the product-packaging development process. 
The setup of the course follows a project-based learning approach, in which students are encouraged to master theoretical knowledge through the active exploration of real-world challenges $[16,33]$. Therefore, a realistic case from a well-known company is used as the starting point to immediately apply both practical and theoretical knowledge. The taxonomy of Bloom [34] was used to structure the course by aligning learning objectives with student assessments. The main learning objective can be formulated as: after finishing the course, the student is able to explain and apply the five crucial perspectives of sustainability and is also capable of designing a packaging concept, integrating these perspectives. As also described by Bloom, this main learning objective contains the most important levels, because students need to understand the knowledge in order to remember it, they need to analyze the knowledge to apply it and finally they need to evaluate the knowledge in order to create new packaging.

The course is divided into 10 weeks where the first seven weeks were used to gain new insights regarding the five perspectives (Figure 2). Every week the students receive both scientific and practice-based knowledge about a different perspective. Parallel to the lectures the students could immediately apply the knowledge in the realistic case. The last three weeks aims at designing a sustainable packaging proposal by synthesizing all available knowledge about the different perspectives. The five perspectives were lectured by the experts in a "colstruction", in which theoretical knowledge is alternated with small-scale practical assignments and discussions.
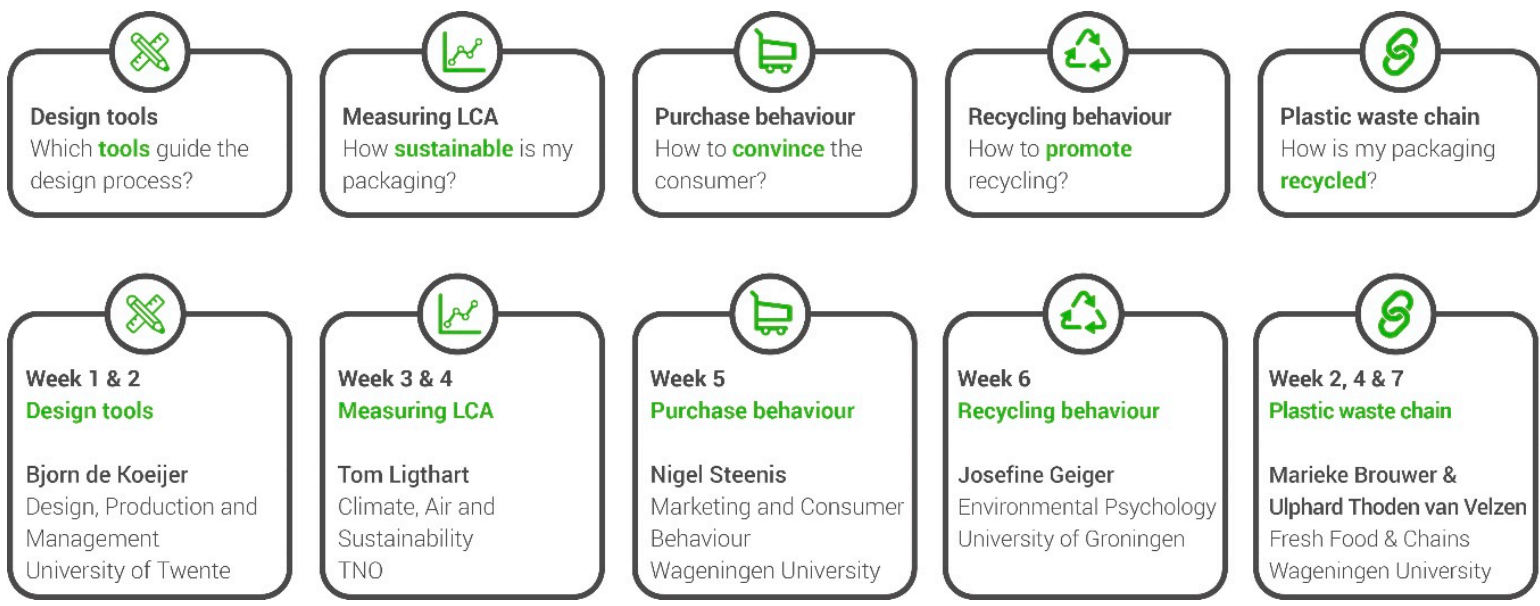

Figure 2. Overview of week planning of the educational module.

16 students of Industrial Design at the University of Applied Sciences in The Hague who specialized in packaging design enrolled on the course, and they were subdivided into four groups. As a final deliverable, they were requested to present their work on an A3-size poster and a short report explaining how the five perspectives influenced their design process and the resulting final design. The outcomes of the educational module can be found in Figure 3. 

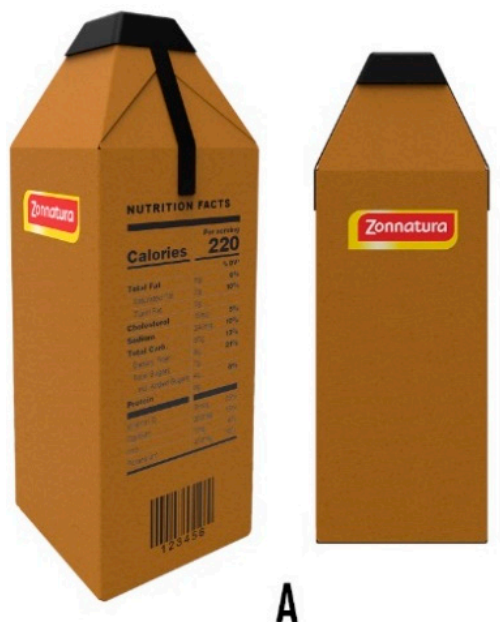

A

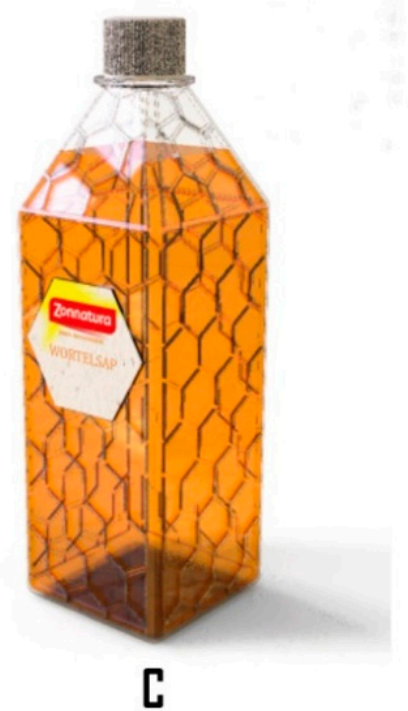

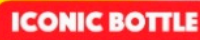

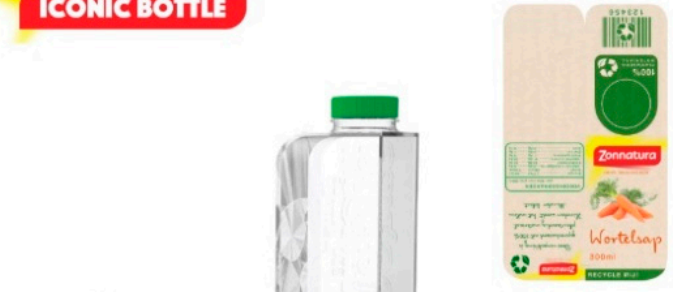

B

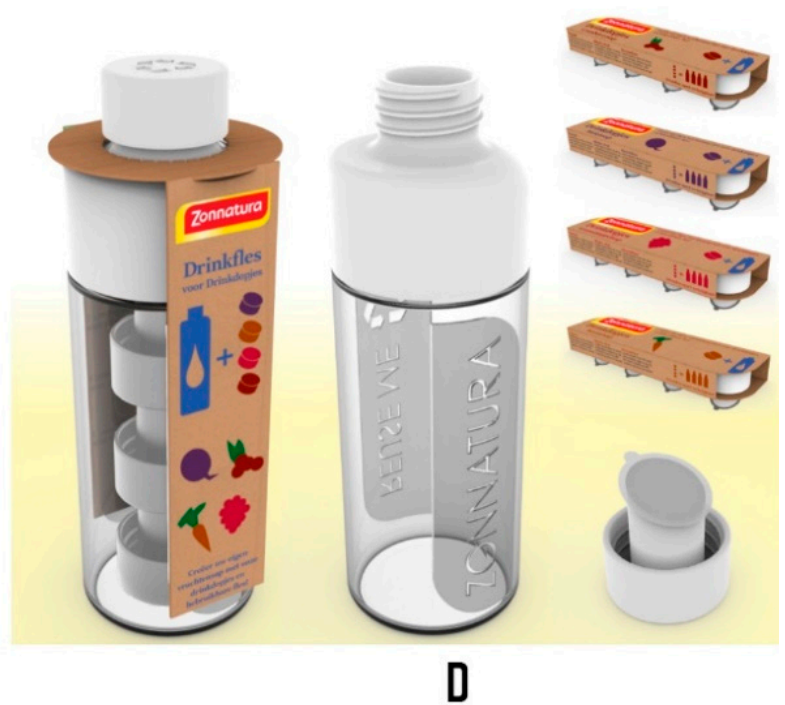

Figure 3. Four designs resulting from the educational module assignment.

\section{Results}

\subsection{Introspective Analysis}

The process and the results of the educational module are assessed via two routes: an introspective analysis, and an expert analysis. The introspective analysis is an assessment conducted by all students that participated in the educational module by means of a reflective measurement on their own results. The aim of the introspective analysis is to determine if students have acquired knowledge on the different perspectives after following the educational module. The aim of the expert analysis is to measure to which degree students are able to integrate the perspectives and apply a holistic approach by means of asking experts to grade the results. The latter will be discussed in Section 4.2. This paper calls into question the ability of students to translate knowledge from multiple fields within the scope of product-packaging development into practical suggestions by reviewing packaging concepts. The targeted students are educated to understand the role of a product designer in the development of product-packaging combinations. The educational program that these students are enrolled in is oriented at applying existing knowledge to develop practical solutions for packaging designs, rather than developing new knowledge. For this reason, testing the students' ability to convert abstract 
scientific insights into meaningful considerations that influence practical design choices is an essential indicator for measuring the impact of the educational module.

To determine to which degree students were able to translate knowledge derived from the educational module into sustainable design considerations for product-packaging from various knowledge bases, two analyses were conducted. The first analysis preceded the educational module and included an individual assignment whereby 16 students were instructed to design a packaging for a drink on-the-go. No limitations, nor requirements, were set for the design, but for clarity the designs had to include a brief, written explanation on their design. This first assignment was a base measurement test that aimed to capture the foreknowledge of the students. At the time of the first analysis, the students were not explicitly familiar with the five perspectives yet, but the students were aware that the educational module would concern sustainability in product-packaging development.

After the courses of the educational module were concluded, the students were asked to improve their own initial designs from the base measurement for the second analysis. For this reflective measurement the students were instructed to sort their suggestions into the five perspectives and include at least one advice per perspective. By letting the students reflect on their own designs by using sticky paper notes, we aimed to retrieve concise practical recommendations for improvements.

In an attempt to structure the quality of the provided answers, we applied a classification of learning objectives that resemble the learning goals of the course. Table 1 shows how we distinguished three levels of learning objectives: applying, understanding, and remembering, and determined for each level a decision criterium to determine the quality of the answer. The three levels of learning objectives, hence the chosen names, were inspired by the bottom levels within the cognitive domain of Bloom's taxonomy for two reasons [34]. First, the categories of Bloom were also used to develop the educational module. Second, Bloom's taxonomy provided a structure with existing defined levels and thereby a systematic way to classify answers that were brief and often inconclusive.

For the decision criteria, we separated suggestions between "concrete" (the suggestion is clear and sound), "vague" (the suggestion is lacking in detail), and "unclear" (the suggestion is confusing). In addition, we checked whether the provided answer belonged to the correct topic. Answers that did not include suitable information were put together in the category "not useful". To reach the level of "applying", the answer needed to be a concrete suggestion for improvement in the correct topic. Reaching "understanding" required either a concrete suggestion in the wrong topic, or a vague suggestion in the right topic. For "remembering", a vague suggestion in the wrong topic, or an unclear suggestion in the right topic was enough. In our view, answers that reached the level of remembering or higher indicated an increase in knowledge, and answers that reached the level of understanding were considered as growth of the competence of the student to apply the acquired knowledge in practice.

As shown in Table 1, examples of answers by students, and our allocated levels are: "Make it easy to recycle for the consumer. Communicate how to recycle and what material it is made from." (applying); "Greenwashing. Make the cup green. Emphasis on the open and closure feature." (understanding); "For the engineers it is easy to make but for marketing it is boring." (remembering); and "Aluminum is awesome!" (no observation of an increase in knowledge perceived). 
Table 1. Decision criteria for the classification of learning objectives and examples of answers

\begin{tabular}{|c|c|c|c|c|}
\hline $\begin{array}{c}\text { Classification of } \\
\text { Learning Objective }\end{array}$ & $\begin{array}{l}\text { Decision Criterium to Determine } \\
\text { the Quality of the Answer }\end{array}$ & Example 1 & Example 2 & Example 3 \\
\hline Applying & $\begin{array}{l}\text { Concrete suggestion for } \\
\text { improvement that is assigned to the } \\
\text { requested perspective }\end{array}$ & $\begin{array}{l}\text { "Explain how to dispose. } \\
\text { Recyclability promotion using logos } \\
\text { on labelling." }\end{array}$ & $\begin{array}{l}\text { "Make it easy to recycle for the } \\
\text { consumer. Communicate how to } \\
\text { recycle and what material it is } \\
\text { made from." }\end{array}$ & $\begin{array}{l}\text { "Clear communication is important } \\
\text { on how it works. The sustainability } \\
\text { aspect is unclear to the consumer." }\end{array}$ \\
\hline Understanding & $\begin{array}{l}\text { Vague suggestion assigned to the } \\
\text { requested perspective; or a concrete } \\
\text { suggestion for an } \\
\text { alternative perspective }\end{array}$ & $\begin{array}{l}\text { "Remove label. Choose the correct } \\
\text { materials, that are compatible with } \\
\text { sorting. Transparent/white colors to } \\
\text { prevent contamination." }\end{array}$ & $\begin{array}{l}\text { "Greenwashing. Make the cup } \\
\text { green. Emphasis on the open and } \\
\text { closure feature." }\end{array}$ & $\begin{array}{l}\text { "Use logos or images to } \\
\text { improve recyclability." }\end{array}$ \\
\hline Remembering & $\begin{array}{l}\text { Unclear suggestion, but recalled } \\
\text { concepts or phrases that relate to the } \\
\text { requested perspective; or vague } \\
\text { suggestion for an } \\
\text { alternative perspective }\end{array}$ & $\begin{array}{l}\text { "Make different materials easily } \\
\text { separable from each other." }\end{array}$ & $\begin{array}{l}\text { "Use two different materials that } \\
\text { you can recycle in one bin." }\end{array}$ & $\begin{array}{l}\text { "For the engineers it is easy to make } \\
\text { but for marketing it is boring." }\end{array}$ \\
\hline $\begin{array}{l}\text { Not useful; no observation of an } \\
\text { increase in knowledge perceived }\end{array}$ & $\begin{array}{l}\text { No suggestion for improvement } \\
\text { provided; or the answer does not } \\
\text { include relevant information; or is } \\
\text { an unclear suggestion for an } \\
\text { alternative perspective }\end{array}$ & "Aluminum is awesome!" & $\begin{array}{c}\text { "The product is already made from } \\
\text { a single material therefore disposing } \\
\text { of packing is simple." }\end{array}$ & “Use paper!” \\
\hline
\end{tabular}


For the base measurement, 14 out of 16 students included a total of 25 comments to their drawings. The most striking result to emerge from the data is that 13 of those 25 comments were related to life cycle analysis. Overall, the base measurement comments remained on the surface, with suggestions as for instance: "use one material", "use less material", or "material recyclable". These ill-defined suggestions from the base measurement offer additional support for increasing the insight of packaging development students about sustainable design considerations.

In contrast to the base measurement, the reflective measurement included more concrete suggestions. Following our decision criteria, the total of 75 answers was distributed along the learning levels as follows: applying (13), understanding (27), remembering (23), and not useful (12). This result indicates that 63 out of 75 answers showed evidence of an increase in knowledge.

Table A1 (Appendix A) shows the division of the answers amongst the subject areas. As expected, the marketing, design, and development perspective was the most difficult for students. Nonetheless, at 4 out of 15 comments, it scores the highest on the learning level applying. Figure 4 shows the division of the answers between the subject areas for the base measurement and the reflective measurement. For the reflective measurement, only the suggestions that reached the learning levels "applying" and "understanding" were counted since these answers indicated an increase in applicable knowledge, as opposed to merely remembering relevant terms. The most surprising result of the reflective measurement is that, while all answers increased in clarity compared to the base measurement, the suggestions related to life cycle analysis were not significantly better than the answers for other subject areas. This result contrasted our expectations based on the results of the base measurement and is clearly reflected in a more equal division between the subject areas as seen in the bar chart of Figure 4 . We assume that this also reflects an increase in adopting a holistic view by the students, because contrary to the base measurement, students were better able to formulate concrete design choices related to all subject areas of sustainability instead of limiting themselves to life cycle analysis. Thus, this finding validates that after following the educational module, the students were better able to incorporate knowledge from multiple disciplines into design choices that increase the sustainability of packaging designs.

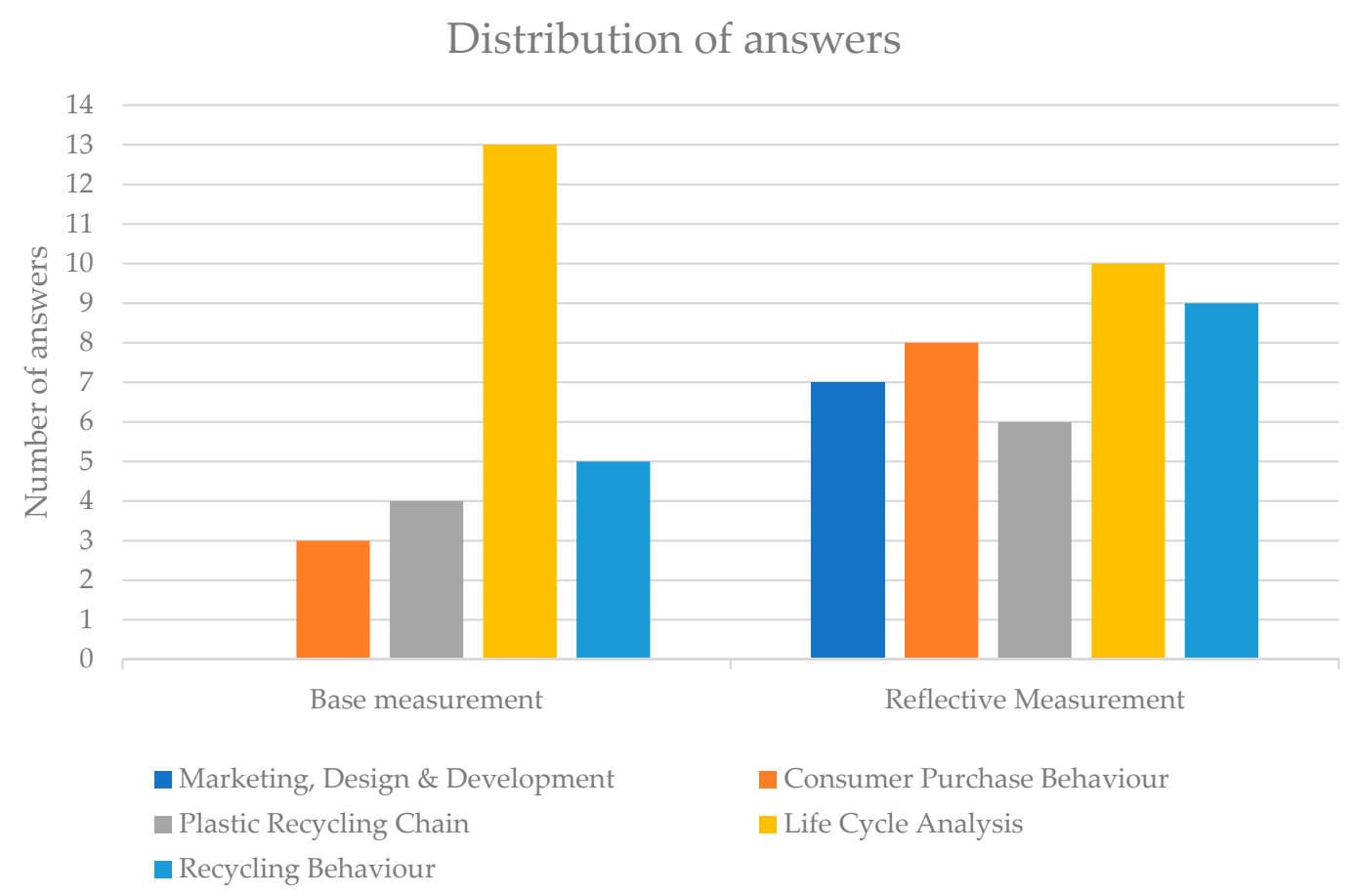

Figure 4. Distribution of answers between the subject areas for the base measurement and the reflective measurement. 


\subsection{Expert Analysis}

To test the applicability and efficacy of the educational module, it is essential to measure if all the perspectives are taken into account in the newly created product-packaging combinations. The main objective of the course, as discussed previously, will be used to test if the students succeed in this task. The designs created by the students are evaluated qualitatively by means of asking experts about the various perspectives. The scope of this expert-analysis is to evaluate if the students are capable of understanding but also applying the scientific knowledge in their designs. The five experts who lectured the students about their respective perspective were responsible for naming three experts in each of their specific working areas. In total, 15 experts were asked to evaluate the four designs, which are shown in Figure 3.

The experts had to follow a specific form using three steps to evaluate all the designs. First of all, they were asked to rate the design by assigning a grade based only on the poster. We requested the experts to first have a look at all the posters, and subsequently grade all the designs at once. The experts could justify their grade with comments. Secondly, they were asked to read the specific part of the report relevant to their specific field and assess the learning objectives of the course. Those learning objectives were specifically written in their field and divided into two levels (understanding and applying). The assessment of the learning objectives was divided into four levels, describing each level in detail. The levels are described as follows:

- Level 1-demonstrated knowledge is limited. Students show poor understanding of the material and demonstrate weak ability to form a judgement.

- Level 2-The content of the work is sufficient, but the chain of reasoning is weak. The basic requirements are fulfilled despite several shortcomings.

- Level 3-Students show good insight in the learning material and correctly applied the knowledge in their work. Nonetheless, a critical view is absent or non-convincing.

- Level 4-Demonstrated knowledge is convincing in the report and the presentation. Deliberate decisions, from a critical perspective, were made during the process and the final design.

In an assessment criteria matrix the more specific information per perspective is described (see Figure 5 and Appendix $C$ for a full overview of all questions per perspective), where the experts are able to highlight the correct level (yellow) and add comments (pink) to explain their considerations more precisely. Again, we requested to justify why the experts selected a certain level by adding comments. Finally, they had to rank the four designs again, from best to worst, and add their final comments.

Since it is difficult for the experts to assess if a specific design succeeds or fails to meet the learning objectives, we decided to evaluate all the comments written down in the extensive evaluations of the experts. In the analysis of the comments, we searched for words and terminology that explains the quality of the results, as also described in the levels of Bloom. To say if the designs have met their main learning objectives, we will use the conscious competence model, which describes learning along two dimensions: "consciousness" and "competence" [35]. This model supports us in differentiating if students have gained knowledge (going from unconscious incompetence to conscious competence) to whether they can also use the knowledge themselves (going from conscious incompetence to conscious competence). In addition, to make the division of levels even more clear, we highlighted in white when the designs fit to this specific field (Figure 6). In this way, we were able to classify all the comments of the experts. 
Assessment Criteria Matrix

\begin{tabular}{|c|c|c|c|}
\hline & & Comments & $\begin{array}{l}\text { Demonstrated knowledge } \\
\text { is limited. Students show } \\
\text { poor understanding of the } \\
\text { material and demonstrate } \\
\text { weak ablity to form a } \\
\text { judgement. }\end{array}$ \\
\hline & & & Level 1 \\
\hline 1 & Lifecycle Assessment & & \\
\hline 1,1 & $\begin{array}{l}\text { Have the students } \\
\text { consistently applied the } \\
\text { terminology of lifecycle } \\
\text { assessment in the poster } \\
\text { and the report? }\end{array}$ & & $\begin{array}{l}\text { Terminology is either } \\
\text { absent or applied } \\
\text { incorrectly in the report } \\
\text { and the poster. }\end{array}$ \\
\hline \begin{tabular}{|l|}
1,2 \\
\end{tabular} & \begin{tabular}{|l|} 
Are the outcomes of the \\
LCA tool used to evaluate \\
different kinds of \\
packaging?
\end{tabular} & $\begin{array}{l}\text { It seems the LCA-tool is used to check the impact of multiple use as well as } \\
\text { a comparison with a conventional bottle. Thus, the tool is indeed put to } \\
\text { good use. However, the assessment leaves me with two important } \\
\text { questions: } \\
\text { - How was Tritan modelled? Tritan is a co-polymer, quite a technical } \\
\text { material. I doubt that it is present in the LCA-tool. So did the students use } \\
\text { a common plastic instead? } \\
\text { - How was the re-use of the bottle modelled in the LCA-tool? I ind it weird } \\
\text { that the impact of raw materials (the red bar) and production llight blue } \\
\text { barr) do not notably decrease when the botrle is re-used } 10 \text { times. The } \\
\text { bottle is the heaviest component, so I would think that re-use of this } \\
\text { component would lower the results much more than shown. } \\
\text {-Can Tritan really be recrcled via source separation? On the website I see } \\
\text { that it is a co-polymer, so it is not a 'clean and simple' polymer like PP or } \\
\text { PET. }\end{array}$ & $\begin{array}{l}\text { The output of the tool is } \\
\text { used incorrectly (e.g. } \\
\text { wrong conclusions from } \\
\text { graphs or information is } \\
\text { missing). }\end{array}$ \\
\hline 1,3 & $\begin{array}{l}\text { How did the results of the } \\
\text { LCA tool influence the } \\
\text { design process, and the } \\
\text { final design? }\end{array}$ & 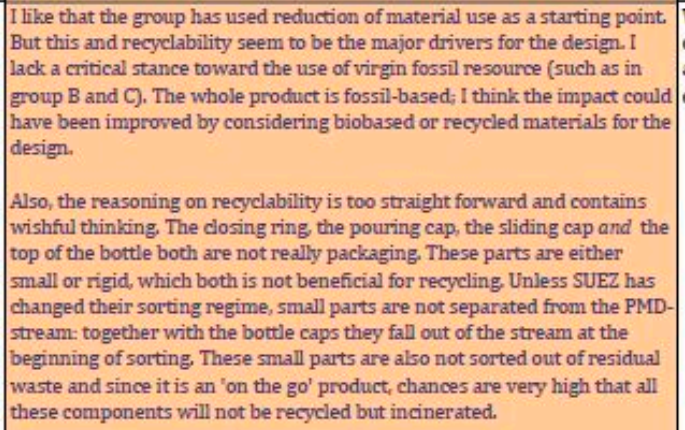 & $\begin{array}{l}\text { Weak to non-existing } \\
\text { correlation between LCA } \\
\text { and design process or final } \\
\text { design. }\end{array}$ \\
\hline
\end{tabular}

UNIVERSITY OF TWENTE.

\section{The content of the work is Students show good insight Demonstrated knowledge is} \begin{tabular}{l|l|l} 
sufficient, but the chain of & in the learning material \\
reasoning is weak. The & convincing in the report and \\
and correctly applied the presentation Deliberate
\end{tabular} kasic requirements are $\quad$ knowledge in their work, decisions, from a critical hortcomings. is absent or non-

perspective, were made final designt.

Level 2
Lonvincing, Level 4

\begin{tabular}{|c|c|c|}
\hline $\begin{array}{l}\text { Terminology is correctly } \\
\text { applied in the report and } \\
\text { the poster, but the } \\
\text { explanation falls behind. }\end{array}$ & $\begin{array}{l}\text { Terminology is correctly } \\
\text { and consistently applied in } \\
\text { the report and the poster. } \\
\text { The work meets the } \\
\text { expectations but does not } \\
\text { exceed them. }\end{array}$ & $\begin{array}{l}\text { The group can explain } \\
\text { definitions, impact categories } \\
\text { and impact assessment } \\
\text { methods. Terminology is } \\
\text { consistently applied in the } \\
\text { report and the poster. }\end{array}$ \\
\hline $\begin{array}{l}\text { The graphs are created } \\
\text { correctly, with reasonable } \\
\text { assumptions, but the } \\
\text { conclusions derived from } \\
\text { the results are weak. }\end{array}$ & $\begin{array}{l}\text { The LCA results are } \\
\text { satisfying and adequate, } \\
\text { but a critical view is } \\
\text { absent }\end{array}$ & \begin{tabular}{|l|} 
Students do not shy away \\
from a critical attitude \\
towards the output of the tool \\
and are able to elaborate on \\
the results of the LCA.
\end{tabular} \\
\hline $\begin{array}{l}\text { The results of the LCA tool } \\
\text { are mentioned but the link } \\
\text { between the results and } \\
\text { their effect on the design } \\
\text { remains unclear. }\end{array}$ & $\begin{array}{l}\text { It is convincing for the } \\
\text { reader that the } \\
\text { considerations made by } \\
\text { the group during the } \\
\text { design process, trace back } \\
\text { to the results of the LCA } \\
\text { tool }\end{array}$ & $\begin{array}{l}\text { The students clearly explain } \\
\text { why they accepted or ignored } \\
\text { certain results and how the } \\
\text { LCC influenced both the } \\
\text { process, and the design. }\end{array}$ \\
\hline
\end{tabular}

Figure 5. Overview of assessment criteria matrix filled in by an expert of the LCA perspective. 
The transition from unconscious incompetence to conscious incompetence indicates the "understanding" of theoretical insights, whereas the transition from conscious incompetence to conscious competence indicates the "applying" level as previously described. The transition from conscious competence to unconscious competence indicates the level of "mastering".

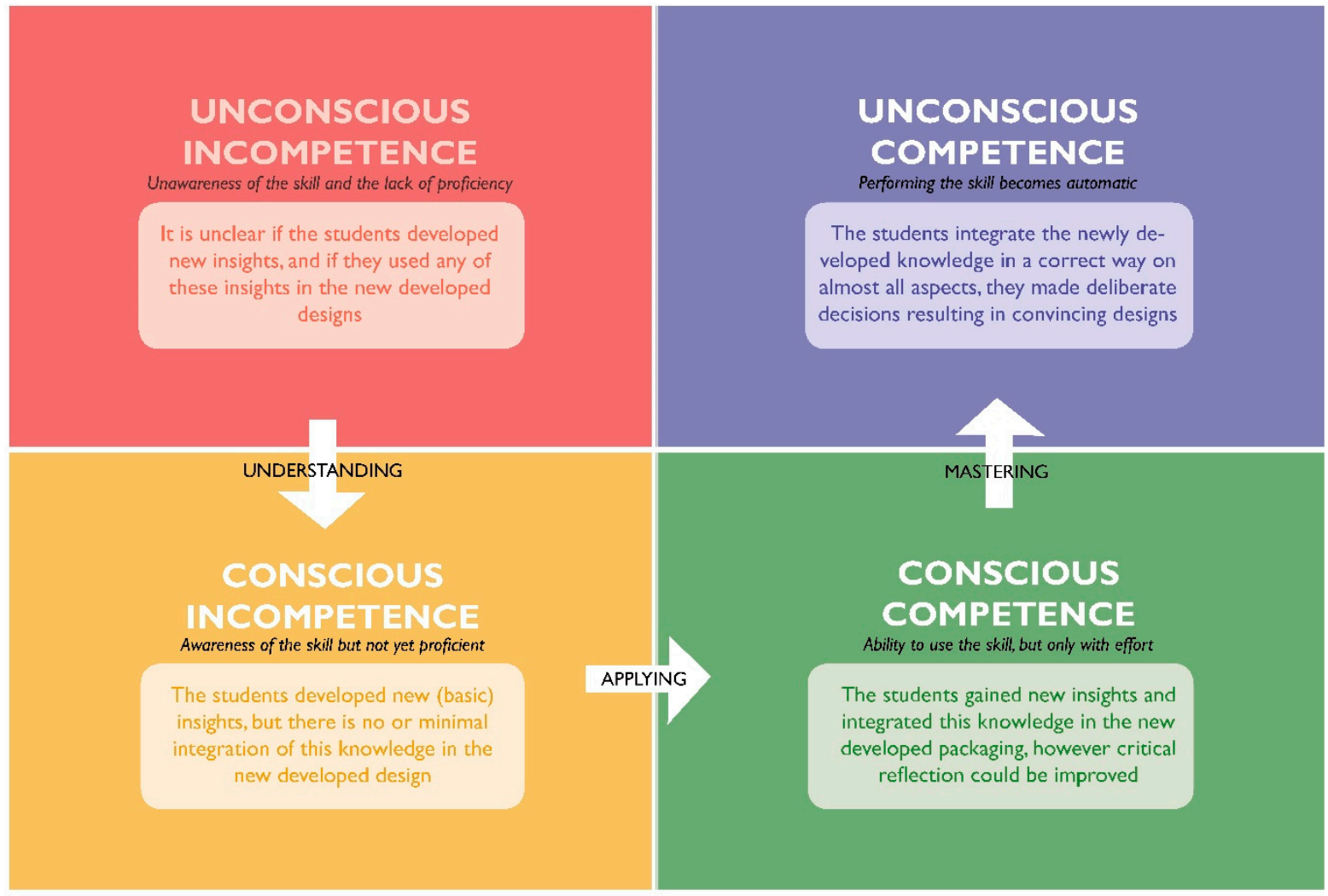

Figure 6. Overview of the conscious-competence model.

The results are based on two aspects: firstly, the grading scores rated by the experts themselves and the differences between the various perspectives, and secondly the classification of all comments in the conscious-competence model.

The grading scores show that concept B was graded as highest with an average score of 7.9 (M 7.93, SD of 0.70), while concept A was graded lowest with an average score of 6.2 (M 6.23, SD of 1.13). Concept $C$ scored an average of 7.4 (M 7.37, SD 1.18) and concept $D$ an average of 7.3 (M 7.27, $\mathrm{SD} 1.23)$. These results clearly show that the experts' opinions were most uniform regarding concept $B$, regarding the low SD value. Surprisingly, concept $C$ and D are graded almost equally, while the comments used to grade concept $\mathrm{D}$ described more positive quotes compared to concept $\mathrm{C}$. However, the grading scores show that concept $C$ is even graded slightly better as concept $D$. In addition, we could conclude that the high SD value of concept $C$ and $D$ indicates the level of diversion between the answers. To get a better understanding, it could be interesting to consider the differences in grading per perspective and the comments that are used to justify their grades.

The scores from the first question where the experts were requested to score the design, together with the quotes show a clear and convincing picture (Figure 7) from which to draw conclusions. In this picture, we see an overview of the grades divided per perspective categorized per design. In this overview the perspectives are shown with a colored line and an abbreviation of the perspective. The abbreviations represent: RB (recycling behavior), LCA (life cycle analysis), CPB (consumer purchase behavior), MDD (marketing, design, and development), and PRC (plastic recycling chain). We can conclude that all graders agree about design $\mathrm{B}$. The differences between the grading is negligible (difference in grades between lowest and highest average grade is less than 0.7). Furthermore, we 
could say that designs A and D are most fluctuating (difference between grades is respectively 2.17 and 1.84), whereas MDD experts especially show a more extreme negative reaction. Both quotes in Figure 7 explain "difficulties" regarding the closure of the design. However, MDD experts tend to be more critical towards the integration and justification of all elements, compared to the PRC expert who mentions the critical aspects, but still values the overall design. For concept $D$, it is the other way around. All three quotes in Figure 7 mention the promising and well-thought-out idea behind concept D. However, MDD experts praise the positive and holistic attitude of the group, while the end of life experts (PRC and RB) are more critical towards problems that could occur during the end of life of this concept. Surprisingly, the LCA experts (red line) are in general more positive about the results during grading. However, reading their comments suggests that a lot of improvements still can be made.

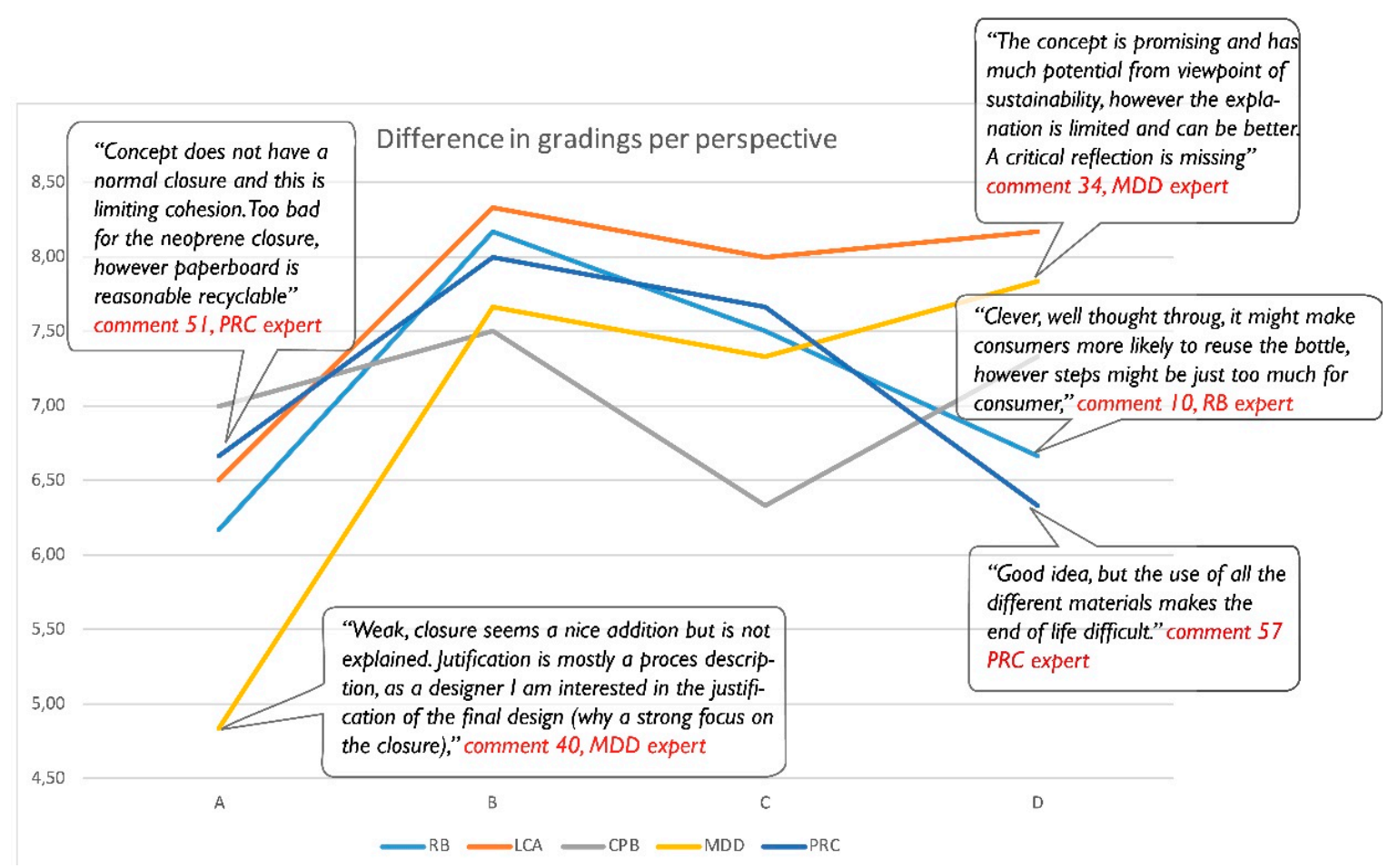

Figure 7. Overview of difference in grading per perspective categorized per design.

Besides the overall grading of the experts, we decided to classify their quotes and dividing them in a conscious-competence model. In total, 57 comments were classified based on the verbs and adjectives they used in their comments. Out of these, we highlighted the most important quotes which indicate where we placed them in the conscious-competence model. An example of the quotes can be found in Figure 8. All the numbered comments and a justification of the classification can be found in Appendix B.

The results show a higher distributed allocation in the level "applying" (23 out of 57 quotes) versus the level "understanding" (17 out of 57) as can be seen in Figure 8. The "mastering" level shows a limited number of quotes (6 out of 57) versus the level "unclear" (red square) which shows 11 out of 57 comments. These results indicate that 30 percent understands the important influence of the five perspectives and 40 percent reached the level of applying those perspectives in their final designs. However, it also means that 19 percent of the students did not reach the levels of "understanding", "applying", or "mastering" and failed to meet the main objective of the course. 


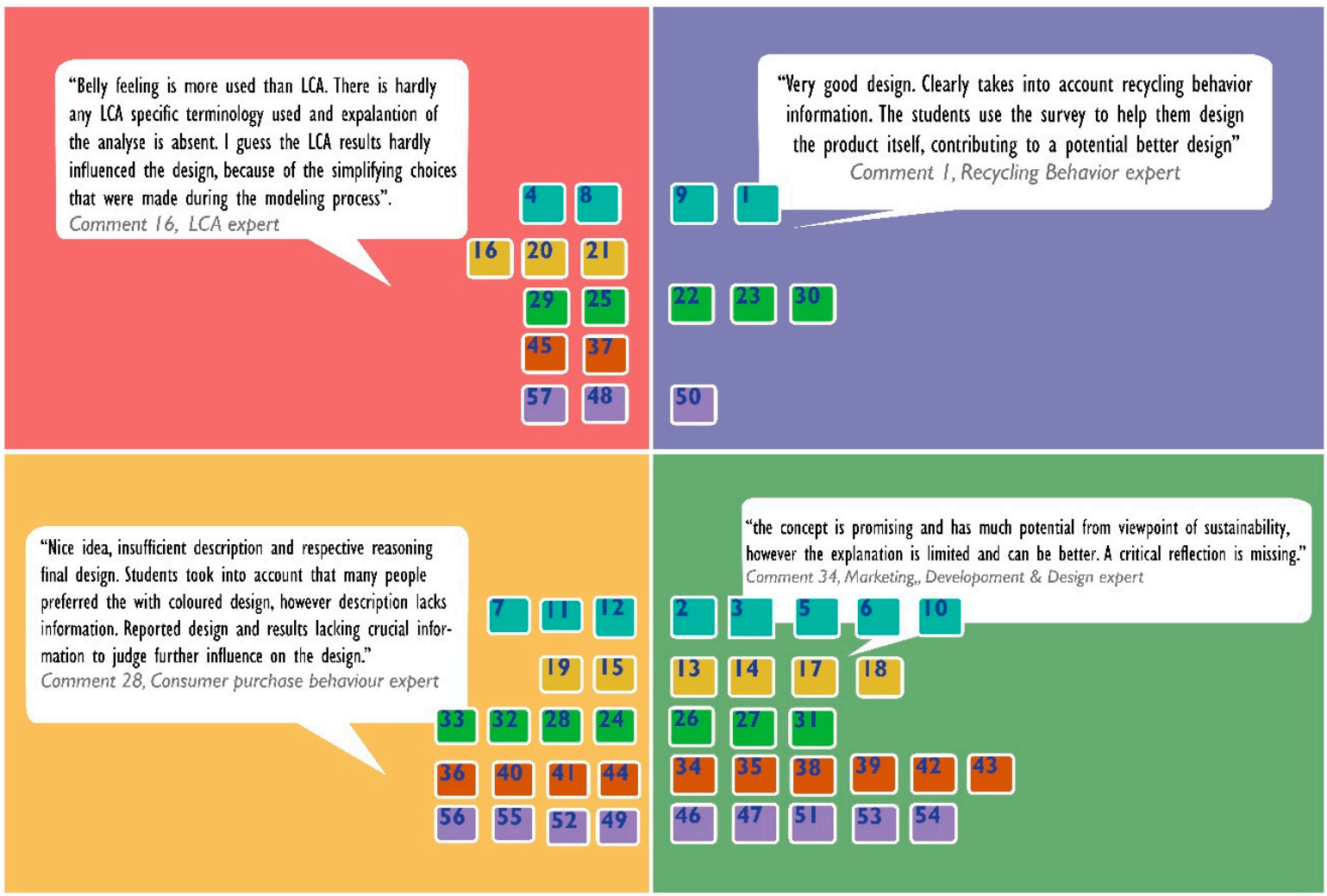

Figure 8. Overview of the classification of all the comments in the conscious-competence model.

\section{Design Game}

Within the educational module, the real-life packaging design case forms the core of the development process by which students integrate the newly acquired packaging sustainability knowledge. This development process revolves around a project guidance tool in the form of a "design game", a serious gaming concept. Within the design game, the synthesis of the various packaging sustainability perspectives, and the simulation of a design and development process are key, aligning with the core focus of the educational module. Besides the development of packaging concepts within the scope of the packaging design case, the main goals of the design game are the explication of development trade-offs and stakeholder interrelations, and the clarification of discussion and decision-making criteria.

\subsection{Team Dynamics}

The core of the simulation of the development process as an educational intervention is the student group's dynamics as members of a product-packaging development team. We expect the student groups to act and interact as a multidisciplinary team, similar to development teams in practice. Within the student teams, the various disciplines are predetermined, to guide the students in their development process. Within the design game (and thus the packaging design case), we specified five disciplines (or roles)—each with specific points of focus. Since each team consists of four students, they are forced to divide the five roles according to their own preferences. We provided the students with brief descriptions of the roles:

- Project manager. This role mainly targets overall project governance, business case feasibility, and overall (estimated) project and product/packaging costs;

- Marketer. Focusing on the alignment of development decisions with commercial issues and market request ("voice of the consumer"); 
- Packaging designer. Key focus on the graphical design and the overall appearance of the packaging design concepts;

- Packaging engineer. This role covers the structural development and the technical requirements of the packaging design concepts;

- Sustainability guardian. The sustainability guardian focuses on the structured implementation of sustainability considerations in the development processes.

Of these roles, the sustainability guardian is the novel extension to a typical product-packaging development team. Therefore, we further address this role's characteristics and added value.

\section{The Sustainability Guardian}

For a product-packaging development process in which sustainability considerations play a key role, the sustainability guardian poses a valuable addition to a development team. Research indicates that the structured implementation of sustainability considerations in product-packaging development processes can benefit from a revision of team dynamics (see e.g., [36-40]). Within the scope of the educational module and the design game, we focus this revision on teams' multidisciplinarity (as described) and the role of a sustainability guardian. The addition of a sustainability guardian benefits the product-packaging development by its ability to balance sustainability-related trade-offs in development processes, following De Koeijer et al. (2017) [3]. This addition of a sustainability guardian to a development team must result in a more firmly established focus on sustainability considerations, balancing the more traditional stakeholder targets, such as costs and a product-packaging combination's market proposition and business case. This echoes sustainability ambitions mainly driven by profit-driven and marketing-related considerations [41-46], in contrast to a company's more holistic sustainability ambition [38,44-49].

The added value of a sustainability guardian relates to its position within a multidisciplinary product-packaging development team, as a key stakeholder in addition to marketers and packaging developers (designers and engineers), following findings by De Koeijer et al. (2017) [3] and Petala et al. (2010) [50]. In a multidisciplinary team, the implementation of a sustainability guardian can materialize in one of three options: (1) as a stakeholder in addition to the team, (2) as a stakeholder taking up the sustainability guardian's role as an additional responsibility, or (3) as a shared team effort.

\subsection{Gaming Process}

The process of (re)designing packaging concepts by means of the design game consists of seven steps. In the first step, the student teams divide the development roles, following the brief role descriptions; in each team, the five roles must be represented by a division according to the preferences of the students. The second step of the Design Game covers the formulation of design requirements, following the specific real-life case's design brief. In the third step, this is followed by a "quick and dirty" design phase, in which each team member individually drafts a design idea, considering the design brief, the requirements, and the role(s) which they represent.

After these start-up steps, the fourth design game step covers the visualization of development trade-offs. In this step, each design proposal is mapped on the "idea board", accompanied by a brief pitch by the responsible designer. After that, each team member must rate the designs, by means of placing score cards (ranging from -3 to +3 ) on the idea board. This rating is done according to each team member's role. This rating results in an overview as illustrated in Figure 9-in this example, four designs are rated by four team roles. Note: if one of the team members is unsure of the design, a score card with a question mark can be placed on the board, indicating that more information is required before scoring the design idea. 


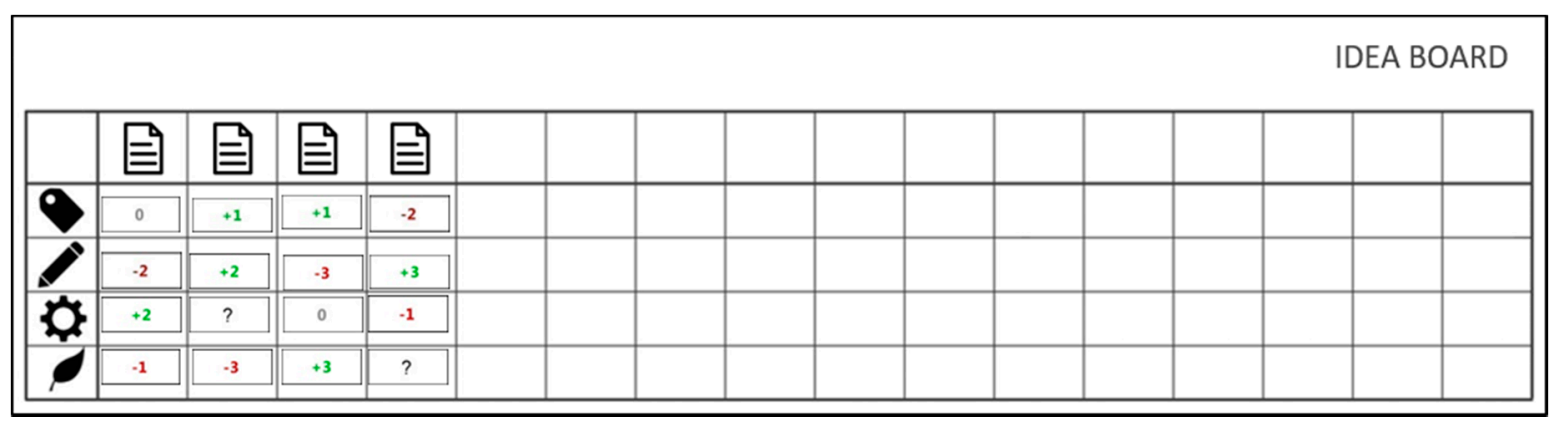

Figure 9. Design game "idea board" with rated designs (example).

As soon as all design ideas have been rated, the team must select one of the options as their preferred concept. This selection can be done in various ways: the design idea which has not been rated any "negatives", the design idea which has the highest accumulated score, or the design idea which is preferred by one of the roles, for instance the sustainability guardian or the project manager. This selection approach is determined by the team and is representative of the team dynamics that are at play. By means of this rating and selection system, the development team is forced to make trade-offs explicit, and discuss these, as also addressed by Mulder-Nijkamp et al. (2018) [23]. It is in the best interest of the development team to select the "best" design option, and therefore it is essential to focus on a proper rating and selection, and substantiation of it.

These steps of the design game can be executed multiple times, according to the preferences and requirements of each development team. For instance, a development team can decide to play the design game to determine an overall design, followed by sequential games focusing on a packaging's main body, a closure, and the packaging graphics.

\subsection{Findings}

The design game produces two types of findings, relevant for this article: the insights in the student development team dynamics, and the tangible packaging concepts as part of the real-life design case. The latter is discussed in Section 4, as the results of the overall educational module. Therefore, in the current section we focus on the findings related to team dynamics, and specifically the role of the sustainability guardian. Out of the four product-packaging development processes conducted by the student teams, three proved to be usable; the results of team C contained too little information to be able to analyze the team dynamics.

\subsubsection{Team A}

In team A, each student selected one of the "traditional" roles as their core role. In addition, the team decided to add the role of the sustainability guardian to the student acting as the team manager. In the development process, the key trade-offs relate to sustainability versus use and consumption considerations, and product branding. For team A, the design game was found to be a relevant design tool to determine options and alternatives for the closure of the packaging concept.

\subsubsection{Team B}

Team B determined the sustainability guardian as a role in addition to a development team, taken up by one of the team members as a core role. Following, the remaining three students divided the four traditional development roles, of the project manager and marketer role are taken up as a combined role. Within the product-packaging development process, many of the trade-offs involved sustainability considerations, with the sustainability guardian as its representative. 


\subsubsection{Team C}

For team C, the students made the decision to mainly focus on the "content-focused" roles. The project manager role remains undetermined, and is therefore an (implicit) shared team effort. Similar to team B, the students focus on sustainability-related trade-offs: mainly in relation to the packaging's closure mechanism, and the overall packaging design (packaging shape and color).

\section{Discussion}

This paper describes the quality of the results of an educational module, integrating five different perspectives on designing sustainable packaging with young packaging designers of the University of Applied Sciences in The Hague. Within the educational module, design synthesis is the core feature. Both by the synthesis of semi-related knowledge bases into an integrated entity, and by enabling design students to synthesize these knowledge bases in the real-life design case, the module adds to research and knowledge on integrating operational sustainability efforts in development processes. This added value closely relates to the design game, in which the application of theoretical knowledge materializes.

The design game is applied as a newly developed design tool, aimed at providing students with a tangible option to make trade-offs in design explicit, as a basis for discussion. Following, the student teams are forced to address these trade-offs, and relate these to development team dynamics-especially in relation to sustainability considerations and the role of a sustainability guardian. For example, finding the optimum between sufficient protection for the packed item and using too much materials, is an important trade-off to make. In order to help the students to make decisions on this trade-off, they are encouraged to use a specific LCA tool to calculate the actual sustainability of a packaging proposal. This knowledge forms important content for the decision-making process and during the design game they are challenged to discuss the consequences of certain decisions guided by the experts of the perspectives. The application of the design game is a small-scale interpretation and simulation of the development process, representing a real-life product-packaging development process. However, less tangible development factors are not part of this simulation, such as experience and certain types of specific knowledge. As a result, part of the decisions and trade-offs by the student teams are based on incomplete information and assumptions. However, the main aim of the educational model is not to discuss all specific topics and related knowledge, but to make the most important trade-offs from the five perspectives explicit by learning to discuss about the consequences of certain decisions relating sustainability.

Within the design game approach, the team dynamics and role divisions are key. However, the process and results show that for the students it is a challenge to fully integrate their specific role's characteristics and points of pocus throughout the development process. The students are trained and educated as designers who view product-packaging as integrated entities and consider a wide array of packaging functions and requirements during the development process. Following, by focusing on the role divisions within the current design game approach, we risk an overly forced integration of these roles in the student teams' product-packaging development processes.

The design game approach and the findings show that the role of a sustainability guardian adds to a development team by its dedicated focus on sustainability considerations and balancing these in relation to other development-influencing factors. However, when appointing a sustainability guardian as the key stakeholder-focusing on sustainability considerations in (product-packaging) development processes-we introduce a risk of "sustainability laziness": a limited responsibility or knowledge of sustainability efforts by other stakeholders in the development process [3]. However, with the current scope and broadness of the integration of the role of a sustainability guardian within the student teams, this effect is difficult to assess.

Secondly, we can identify a bias in the efficacy of the sustainability guardian's role. The student groups are aware of the focus on sustainability in product-packaging development, both in the design game and the educational module as a whole. Therefore, it is expected that sustainability will receive more attention in the students' development approaches. When considering the example of student 
teams B and C, the clear focus on sustainability-related trade-offs indicates the significant impact of the sustainability guardian's role. However, the bias effect may have an impact here as well, which has not been tested. The third issue regarding the role of the sustainability guardian is the practical application. Even though the educational module and design game have been developed as a simulation of real-life product-packaging development processes, the actual team dynamics have not been tested in operational product-packaging development practice.

In order to test the efficacy and effectiveness of the educational approach we conducted an extensive introspective analysis and expert analysis. Although the results of the experts' reviews show the students were able to integrate the perspectives, there are some remarks and limitations that need to be discussed.

The approach of the research was qualitative in nature, mainly due to the fact we only had four design proposals to investigate. The extensive analysis of the outcomes of both the introspective as expert review leads to interesting conclusions; however, these conclusions should be further investigated preferably with more design proposals. The expert analysis was mainly based on comments and quotes mentioned by the experts. An important remark that should be taken into account is the difference in grading per person and per perspective. As already indicated previously, the grading scores of the LCA perspective were more positive compared to their comments, this could be influencing the end results. However, we can also point out that the difference in grading within a specific perspective was not that different.

Another discussion point is the classification of all the quotes in the conscious-competence model. It is quite easy to indicate if a designer is competent or not, however, it is quite hard to indicate if the designer is conscious or not. We can identify if a design proposal is viable by means of asking experts, but this does not immediately imply that students made this design more "conscious".

\section{Conclusions}

In this paper, we strived to implement new scientific insights in the educational field of sustainable packaging from various perspectives and focused on integrating and applying those insights by developing an educational module. The holistic approach of the course and the tools that are offered support young packaging designers in making more balanced choices to finally design a product-packaging combination that leads to synthesis of all disciplines. The efficacy and effectiveness of this educational module describing the results of an extensive introspective analysis and expert analysis has shown evidence of students understanding and applying knowledge in their product development process. However, only a few students reached the mastering level.

The added value of the education module closely relates to the focus on design synthesis. Firstly, the module itself targets the integration of semi-related knowledge bases into one synthesized entity. Secondly, the approach of the educational module—especially the design game-enables students to apply this design synthesis of knowledge in their product-packaging development processes.

In order to simulate the complex processes of decision making in product-packaging development, we developed and applied the design game as a project guidance tool. Within this design game, the core characteristics of development relate to team dynamics-specifically the role of the sustainability guardian-and balancing inevitable trade-offs between project- and product-defining factors. This educational intervention of addressing trade-offs and team dynamics within a synthesis-focused development process simulation shapes the core of the educational module.

Strategic commitment and support is a critical enabler of the successful integration of sustainability considerations, following Boks (2006) [39], Hallstedt et al. (2013) [40], Jansson et al. (2017) [48], and Johansson (2002) [38]. Furthermore, for the role of a sustainability guardian to be successful, substantiation and support on a strategic level is required. However, within the scope of this educational module, this is not analyzed. This therefore poses a relevant direction for further research. Also, the practical implementation of the role of a sustainability guardian benefits from research into 
the open-ended nature of the various settings in which this role interacts within a development team, as the findings suggest.

Author Contributions: M.M.-N., B.d.K. and R.-J.T. equally contributed to the scope-setting of the study. Data collection and analysis, M.M.-N., B.d.K. and R.-J.T. Manuscript writing and editing, M.M.-N., B.d.K. and R.-J.T.

Funding: The project is organized by and executed under the auspices of TIFN, a public-private partnership on precompetitive research in food and nutrition. The authors have declared that no competing interests exist in the writing of this publication. Funding for this research was obtained from KIDV and the Top-sector Agri\&Food.

Acknowledgments: The authors wish to thank the HAS University of Applied Sciences, The Hague University of Applied Sciences, and the reviewing experts for their input in this research.

Conflicts of Interest: The authors declare no conflict of interest. The funders had no role in the design of the study; in the collection, analyses, or interpretation of data; in the writing of the manuscript, or in the decision to publish the results.

\section{Appendix A}

Table A1. Distribution of suggestions for improvement and comments added to the base measurement

\begin{tabular}{|c|c|c|c|c|c|c|}
\hline $\begin{array}{l}\text { Classification of } \\
\text { Learning Objective }\end{array}$ & Total & $\begin{array}{l}\text { Design } \\
\text { Models }\end{array}$ & $\begin{array}{l}\text { Consumer } \\
\text { Purchasing } \\
\text { Behavior }\end{array}$ & $\begin{array}{c}\text { Plastic } \\
\text { Recycling } \\
\text { Chain }\end{array}$ & $\begin{array}{l}\text { Life Cycle } \\
\text { Analysis }\end{array}$ & $\begin{array}{l}\text { Recycling } \\
\text { Behavior }\end{array}$ \\
\hline Applying & 13 & 4 & 3 & 1 & 2 & 3 \\
\hline Understanding & 27 & 3 & 5 & 5 & 8 & 6 \\
\hline Remembering & 23 & 4 & 4 & 7 & 3 & 5 \\
\hline $\begin{array}{l}\text { No observation of } \\
\text { an increase in } \\
\text { knowledge }\end{array}$ & 12 & 4 & 3 & 2 & 2 & 1 \\
\hline Total & 75 & 15 & 15 & 15 & 15 & 15 \\
\hline $\begin{array}{l}\text { Base measurement } \\
\text { comments }\end{array}$ & 25 & 0 & 3 & 4 & 13 & 5 \\
\hline
\end{tabular}




\section{Appendix B}

Table A2. Comments and justification of classification.

\begin{tabular}{|c|c|c|c|c|c|c|c|c|}
\hline Uncor & scious Competence & Conscious Competence & & onscious Incompeten & & & conscious Incompetence & \\
\hline $\begin{array}{l}\text { The students } \\
\text { developed kr } \\
\text { on almost all } \\
\text { deliberate de } \\
\text { convincing d }\end{array}$ & $\begin{array}{l}\text { ntegrate the newly } \\
\text { owledge in a correct way } \\
\text { spects, they made } \\
\text { isions resulting in } \\
\text { signs }\end{array}$ & $\begin{array}{l}\text { The students gained new } \\
\text { insights and integrated } \\
\text { this knowledge in the } \\
\text { new developed } \\
\text { packaging, however } \\
\text { critical reflection could } \\
\text { be improved }\end{array}$ & $\begin{array}{l}\text { The students develope } \\
\text { minimal integration of }\end{array}$ & $\begin{array}{l}\text { new (basic) insights, } \\
\text { his knowledge in the } n\end{array}$ & $\begin{array}{l}\text { there is no or } \\
\text { developed design }\end{array}$ & $\begin{array}{l}\text { It is unclear if the stud } \\
\text { of these insights in the }\end{array}$ & $\begin{array}{l}\text { th develop new insights, and if t } \\
\text { ew developed designs }\end{array}$ & ey used any \\
\hline $\begin{array}{l}\text { Overall comme } \\
\text { judgement, wh } \\
\text { the specific que } \\
\text { learning object }\end{array}$ & $\begin{array}{l}\text { Its refer to the final } \\
\text { le specific comments refer to } \\
\text { tions derived from the } \\
\text { ves per perspective (Table A3) }\end{array}$ & $\begin{array}{l}\text { Overall comments refer to } \\
\text { the final judgement, while } \\
\text { specific comments refer to } \\
\text { the specific questions } \\
\text { derived from the learning } \\
\text { objectives per perspective }\end{array}$ & $\begin{array}{l}\text { Overall comments refer } \\
\text { to the specific questions } \\
\text { (Table A3) }\end{array}$ & $\begin{array}{l}\text { the final judgement, whi } \\
\text { rived from the learning o }\end{array}$ & $\begin{array}{l}\text { specific comments refer } \\
\text { ctives per perspective }\end{array}$ & $\begin{array}{l}\text { Overall comments refer } \\
\text { to the specific questions } \\
\text { (Table A3) }\end{array}$ & $\begin{array}{l}\text { the final judgement, while specific ce } \\
\text { rived from the learning objectives pe }\end{array}$ & $\begin{array}{l}\text { nents refer } \\
\text { rspective }\end{array}$ \\
\hline Quote No. & Complete Comment and C & lor & & Initials Perspective & Quotes (Derived fror & e Comments) & $\begin{array}{l}\text { Terminology (Verbs, Nouns, } \\
\text { Adjectives) }\end{array}$ & Design \\
\hline 1 & $\begin{array}{l}\text { OVERALL: Very good desi } \\
\text { information. SPECIFIC: } 1 \text {. } \\
\text { design. These questions we } \\
\text { of the product. } 2 \text {. The exple } \\
\text { them design the product it: }\end{array}$ & $\begin{array}{l}\text { n. Cleary takes into account } \\
\text { he students included key qu } \\
\text { e derived from some of the } \\
\text { nation is clear. The students } \\
\text { alf, contributing to a potenti }\end{array}$ & $\begin{array}{l}\text { e recycling behavior } \\
\text { tions to improve their } \\
\text { ost relevant features } \\
\text { ee the survey to help } \\
\text { better design. }\end{array}$ & RB1 & $\begin{array}{l}\text { Very good design. } \mathrm{Cl} \\
\text { recycling behavior in } \\
\text { use the survey to help } \\
\text { product itself, contrib } \\
\text { better design }\end{array}$ & $\begin{array}{l}\text { rly takes into account } \\
\text { rmation. The students } \\
\text { hem design the } \\
\text { ting to a potential }\end{array}$ & $\begin{array}{l}\text { very good, clearly takes into } \\
\text { account, include key } \\
\text { questions to improve their } \\
\text { design, relevant features, } \\
\text { explanation is clear, } \\
\text { contributing to a potential } \\
\text { better design }\end{array}$ & B \\
\hline 2 & $\begin{array}{l}\text { OVERALL: Very good desi } \\
\text { information as specific inpl } \\
\text { the empirical evidence in a } \\
\text { of the information they coll } \\
\text { as a way of confirming thei } \\
\text { design itself. }\end{array}$ & $\begin{array}{l}\text { n. It would have been nice } t \\
\text { ts for the design. SPECIFIC: } \\
\text { vay that consolidates their } d \\
\text { cted. } 2 \text {. The students used } t \\
\text { design instead of using it as }\end{array}$ & $\begin{array}{l}\text { include recycling } \\
\text { The students used } \\
\text { ign, taking advantage } \\
\text { collected information } \\
\text { intrinsic part of the }\end{array}$ & RB1 & $\begin{array}{l}\text { very good design. Wc } \\
\text { include recycling info } \\
\text { used the empirical ev } \\
\text { consolidates their des } \\
\text { of the information the }\end{array}$ & $\begin{array}{l}\text { ld have been nice to } \\
\text { nation. The students } \\
\text { lence in a way that } \\
\text { nn, taking advantage } \\
\text { collected. }\end{array}$ & $\begin{array}{l}\text { very good design, would have } \\
\text { been nice, consolidates their } \\
\text { design, taking advantage, } \\
\text { used the information, } \\
\text { confirming their design }\end{array}$ & A \\
\hline 3 & $\begin{array}{l}\text { OVERALL: Good design. T } \\
\text { following the evidence. SP } \\
\text { their design, allowing then } \\
\text { However, the complexity o } \\
\text { predicting recycling behavi } \\
\text { complex design to use. } 2 \text {. T } \\
\text { influenced by the findings } \\
\text { regarding how the evidenc }\end{array}$ & $\begin{array}{l}\text { ee project adapts some featu } \\
\text { CIFIC: } 1 \text {. The students used } \\
\text { to propose a potentially mo } \\
\text { the design undervalues son } \\
\text { r, such as self-efficacy, giver } \\
\text { e final design has specific b } \\
\text { f the students. They include } \\
\text { influenced the design itself }\end{array}$ & $\begin{array}{l}\text { Sof the design } \\
\text { eir findings as part of } \\
\text { successful design. } \\
\text { important factors } \\
\text { hat it is a fairly } \\
\text { n specifically } \\
\text { ecific information }\end{array}$ & RB1 & $\begin{array}{l}\text { Good design, adapts } \\
\text { evidence. Students us } \\
\text { of their design, allow } \\
\text { potentially more succ } \\
\text { the complexity of the } \\
\text { some important facto } \\
\text { behavior. Final desigl } \\
\text { regarding how the ev } \\
\text { design itself. }\end{array}$ & $\begin{array}{l}\text { me features following } \\
\mathrm{d} \text { their findings as part } \\
\mathrm{g} \text { them to propose a } \\
\text { sful design. However, } \\
\text { esign undervalues } \\
\text { predicting recycling } \\
\text { includes information } \\
\text { lence influenced the }\end{array}$ & $\begin{array}{l}\text { adapts some, following } \\
\text { evidence, used their findings, } \\
\text { potentially more successful } \\
\text { design, complexity } \\
\text { undervalues important } \\
\text { factors, specifically influenced } \\
\text { by findings, }\end{array}$ & $\mathrm{D}$ \\
\hline
\end{tabular}


Table A2. Cont.

\begin{tabular}{|c|c|c|c|c|c|}
\hline Quote No. & Complete Comment and Color & Initials Perspective & Quotes (Derived from the Comments) & $\begin{array}{l}\text { Terminology (Verbs, Nouns, } \\
\text { Adjectives) }\end{array}$ & Design \\
\hline 4 & $\begin{array}{l}\text { OVERALL: There is no clarification regarding the use of actual recycling } \\
\text { behavior in the design. SPECIFIC: } 1 \text {. The students do not include information } \\
\text { on how the have used evidence-based information (collected by them or using } \\
\text { established theories) to design the product. They rely completely on the local } \\
\text { garbage management center. By doing so, they failed in some of the objectives } \\
\text { of the commissioning company. } 2 \text {. The students used a recycling behavior } \\
\text { concept (i.e., simplicity on recycling) as one of the core ideas to design the } \\
\text { product itself. However, they failed to support this approach, not showing what } \\
\text { is the evidence behind the specific proposal. }\end{array}$ & RB1 & $\begin{array}{l}\text { there is no clarification regarding the use of } \\
\text { actual recycling behavior. Students do not } \\
\text { include information on how they have used } \\
\text { evidence-based information to design the } \\
\text { product. }\end{array}$ & $\begin{array}{l}\text { no clarification, do not } \\
\text { include, rely completely on, } \\
\text { failed in some of the } \\
\text { objectives, failed to support, } \\
\text { not showing the evidence }\end{array}$ & C \\
\hline 5 & $\begin{array}{l}\text { OVERALL: No comments } \\
\text { SPECIFIC: } 1 . x 2 \text {. Clear and very good reasoning on certain design choices } \\
\text { (material, cap, label, recycle logo); good to see that there is also focus on } \\
\text { sustainability and not only on information provision. Students assume that } \\
\text { people will separate label from bottle while disposing the package, i doubt that } \\
\text { if there is no information provided on it on the package. }\end{array}$ & RB2 & $\begin{array}{l}\text { clear and very good reasoning on certain } \\
\text { design choices. Students assume that people } \\
\text { will separate label form bottle, I doubt that if } \\
\text { there is no information provided on it }\end{array}$ & $\begin{array}{l}\text { clear, very good reasoning, } \\
\text { assume, doubt }\end{array}$ & B \\
\hline 6 & $\begin{array}{l}\text { OVERALL: No comments } \\
\text { SPECIFIC: } 1 \text {. Does not contain a report, so cannot judge reasoning. This is a pity, } \\
\text { because the design looks promising (texture and shape to remind people of } \\
\text { nature, recycled paper label). Yet, in the poster, the designers seem very focused } \\
\text { on the sustainability aspect which seems to be important with regard to } \\
\text { recycling. Interestingly, they don't focus on consumers recycling behavior but } \\
\text { on post recycling. Some elaboration would have been interesting. This was only } \\
\text { part of the assignment. I do not see a relation with 'the busy consumers being } \\
\text { on the go'. } 2 . x\end{array}$ & RB2 & $\begin{array}{l}\text { Seem to focus on the sustainability aspect, } \\
\text { interestingly, they don't focus on consumers } \\
\text { recycling behavior but on post recycling. } \\
\text { Some elaboration would have been } \\
\text { interesting. }\end{array}$ & $\begin{array}{l}\text { seem to be important, some } \\
\text { elaboration would have been } \\
\text { interesting, do not see relation }\end{array}$ & C \\
\hline 7 & $\begin{array}{l}\text { OVERALL: It is a different and creative approach to sustainable packages; } \\
\text { however, this package requires time to prepare: people have to fill the bottle } \\
\text { with the cap and then look for a nearby water source. To me, this is very } \\
\text { inconvenient for a busy consumer on the go. In addition, the separate caps } \\
\text { result in lot of waste. SPECIFIC: } 1 . x 2 . x\end{array}$ & RB2 & $\begin{array}{l}\text { different creative approach, however, this } \\
\text { package requires time to prepare: filling is } \\
\text { very inconvenient for a busy consumer on the } \\
\text { go. Separate caps result in lot of waste }\end{array}$ & $\begin{array}{l}\text { requires time to prepare, very } \\
\text { inconvenient }\end{array}$ & D \\
\hline 8 & $\begin{array}{l}\text { OVERALL: Assignment looks not fully understood as the students do not } \\
\text { provide any information on their reasoning with regard to recycling. Materials } \\
\text { in the end not very different from normal packages (only the way to seal it). } \\
\text { One could argue that the aim of Zonnatura is communicated through the } \\
\text { non-bleached material but would have been nice to read about it (package also } \\
\text { does not contain info on what product is inside the package). The way the } \\
\text { packaging is sealed now is not convenient for the busy consumer on to go. They } \\
\text { elaborate on the current situation with regard to recycling bins, which is } \\
\text { important, but focus was on design. SPECIFIC: } 1 \text {. } x \text { 2. Students understood well } \\
\text { that recycling labels are not very effective in promoting recycling behavior and } \\
\text { therefore did not focus on this but rather on the sustainable look which can } \\
\text { promote recycling behavior. Students should have elaborated on this reasoning } \\
\text { a bit more as they now do not provide any information on this. }\end{array}$ & RB2 & $\begin{array}{l}\text { students understood well that recycling } \\
\text { labels are not effective but should have } \\
\text { elaborated on this reasoning a bit more. } \\
\text { Assignment looks not fully understood as the } \\
\text { students do not provide any information on } \\
\text { their reasoning with regard to recycling }\end{array}$ & $\begin{array}{l}\text { not focus on this, should have } \\
\text { elaborated more, assignment } \\
\text { looks not fully understood, do } \\
\text { not provide any information, } \\
\text { does not contain info }\end{array}$ & A \\
\hline
\end{tabular}


Table A2. Cont.

\begin{tabular}{|c|c|c|c|c|c|}
\hline Quote No. & Complete Comment and Color & Initials Perspective & Quotes (Derived from the Comments) & $\begin{array}{l}\text { Terminology (Verbs, Nouns, } \\
\text { Adjectives) }\end{array}$ & Design \\
\hline 9 & $\begin{array}{l}\text { OVERALL: Design clearly based on consumer recycling behavior, as shown by } \\
\text { the results from the survey. The design also clearly states its recycling goals on } \\
\text { main features of the design, making it more likely for consumer to recycle the } \\
\text { product. Also, easy to reuse and take on-the-go. SPECIFIC: } 1 . x 2 . x\end{array}$ & RB3 & $\begin{array}{l}\text { The design also clearly states it's recycling } \\
\text { goals on main features of the design }\end{array}$ & $\begin{array}{l}\text { clearly states, shown by } \\
\text { results }\end{array}$ & B \\
\hline 10 & $\begin{array}{l}\text { OVERALL: Design D is clever and well thought through, regarding all the } \\
\text { different steps consumers could take to make most of the product. Having } \\
\text { refills for the content of the bottle might indeed make consumers more likely to } \\
\text { reuse the bottle, which tops the idea of group B. Also, it clearly states the } \\
\text { recycling goal and how to use it, to its consumer. However, these steps might be } \\
\text { just too much for the consumer to actually make them more likely to recycle the } \\
\text { bottle. In the paper, I did not find a clear reasoning as to why the students think } \\
\text { this might work. Hence, I am not sure whether this will work. If it does, it is } \\
\text { great. SPECIFI: } 1 . x 2 \text {. Understanding of consumers perspective is sufficient } \\
\text { but figures in the paper are unclear/reasoning is lacking. }\end{array}$ & RB3 & $\begin{array}{l}\text { clever, well thought through, it might make } \\
\text { consumers more likely to reuse the bottle, } \\
\text { however steps might be just too much for } \\
\text { consumer, }\end{array}$ & $\begin{array}{l}\text { clever, well thought through, } \\
\text { but did not find clear } \\
\text { reasoning }\end{array}$ & $\mathrm{D}$ \\
\hline 11 & $\begin{array}{l}\text { OVERALL: Natural looking and easy to recycle for the consumer. Apparently, a } \\
\text { clear recycle-icon was incorporated in the design (as was not clear from the } \\
\text { poster). So clearly the consumers recycling behavior is taken into account. } \\
\text { However, as they also state in their report, people indeed might not recycle } \\
\text { paper waste on-the-go as much. Also, they might not take a cardboard bottle } \\
\text { that is hard to seal without spilling its contents on-the-go. Therefore, somewhat } \\
\text { less likely to be recycled by the consumer than the previous designs. SPECIFIC: } \\
\text { 1. X 2. x }\end{array}$ & RB3 & $\begin{array}{l}\text { Apparently a clear recycle-icon was } \\
\text { incorporated in the design, however people } \\
\text { indeed might not recycle paper waste } \\
\text { on-the-go as much }\end{array}$ & $\begin{array}{l}\text { is taken into account, } \\
\text { however, might not be } \\
\text { recycled. less likely to be } \\
\text { recycled }\end{array}$ & A \\
\hline 12 & $\begin{array}{l}\text { OVERALL: Design C also has a natural look. Making people feel more } \\
\text { connected to the natural content of the bottle. In this regard, it is probably the } \\
\text { best of all designs. Also, it is easy to recycle, since it's consumer can throw away } \\
\text { the entire bottle at one (they do not have to separate the different parts). } \\
\text { However, the fact that they should recycle, is not explicitly made clear to the } \\
\text { consumer on the design itself. This might be pivotal for consumers to know. } \\
\text { Unfortunately, there was no report to explain their reasoning. SPECIFIC: } 1 \text {. No } \\
\text { report 2. No report }\end{array}$ & RB3 & $\begin{array}{l}\text { Natural look is probably best of all designs. } \\
\text { However, the fact that they should recycle, is } \\
\text { not explicitly made clear to the consumer on } \\
\text { the design itself. This might be pivotal for } \\
\text { consumers to know. Unfortunately, there was } \\
\text { no report to explain their reasoning. }\end{array}$ & $\begin{array}{l}\text { not explicitly made clear, this } \\
\text { might be pivotal, no report } \\
\text { explaining reasoning }\end{array}$ & C \\
\hline 13 & $\begin{array}{l}\text { OVERALL: Although the explanation is poor, it is clear that the students have } \\
\text { done quite some LCA work to come to their final design. SPECIFIC: } 1 \text {. There is } \\
\text { a correct use of terminology, but the explanation of used methods, units of the } \\
\text { results, etc. falls behind. } 2 \text {. The reader is not taken by the hand when looking at } \\
\text { the results. Only the results that can be seen in the graphs are listed, but the } \\
\text { interpretation or description of the implications is poor. } 3 \text {. Although the } \\
\text { explanation is poor, it is clear that the students have done a series of analyses to } \\
\text { come to their final design }\end{array}$ & LCA1 & $\begin{array}{l}\text { Although the explanation is poor, it is clear } \\
\text { that the students have done quite some LCA } \\
\text { work. There is a correct use of terminology, } \\
\text { but the explanation of used methods falls } \\
\text { behind }\end{array}$ & $\begin{array}{l}\text { explanation is poor, quite } \\
\text { some LCA work, correct use } \\
\text { of terminology, explanation } \\
\text { falls behind, not taken by the } \\
\text { hand, interpretation is poor, } \\
\text { have done series of analyses }\end{array}$ & B \\
\hline 14 & $\begin{array}{l}\text { OVERALL: More or less clear how choices were made, but unfortunately a } \\
\text { detailed report is lacking SPECIFIC: } 1 . x 2 . \times 3 . x\end{array}$ & LCA1 & $\begin{array}{l}\text { more or less clear how choices were made, } \\
\text { but detailed report is lacking }\end{array}$ & $\begin{array}{l}\text { more or less clear, detailed } \\
\text { report lacking }\end{array}$ & C \\
\hline
\end{tabular}


Table A2. Cont.

\begin{tabular}{|c|c|c|c|c|c|}
\hline Quote No. & Complete Comment and Color & Initials Perspective & Quotes (Derived from the Comments) & $\begin{array}{l}\text { Terminology (Verbs, Nouns, } \\
\text { Adjectives) }\end{array}$ & Design \\
\hline 15 & $\begin{array}{l}\text { OVERALL: Due to the poor explanation, it is not clear to the reader whether the } \\
\text { LC analyses that were performed have influenced the choice of materials and } \\
\text { other design choices, or that 'belly feeling' was playing a major part here. } \\
\text { SPECIFIC: } 1 \text {. There is a correct use of terminology, but the explanation of results } \\
\text { falls behind. Only highlights / conclusions are presented as results. } 2 \text {. The } \\
\text { reader is not taken by the hand when looking at the results. Only the results } \\
\text { that can be seen in the graphs are listed, but the interpretation or description of } \\
\text { the implications is poor. 3. Due to the poor explanation, it is not clear to the } \\
\text { reader whether the LC analyses that were performed have influenced the choice } \\
\text { of materials and other design choices, or that 'belly feeling' was playing a major } \\
\text { part here. }\end{array}$ & LCA1 & $\begin{array}{l}\text { It is not clear whether the LC analyses have } \\
\text { influenced the choice of materials or that } \\
\text { belly feeling was playing a major part here. }\end{array}$ & $\begin{array}{l}\text { poor explanation, not clear } \\
\text { whether the LC analysis have } \\
\text { influenced, belly feeling, } \\
\text { correct use of terminology, } \\
\text { explanation falls behind, not } \\
\text { taken by the hand, } \\
\text { interpretation is poor. }\end{array}$ & D \\
\hline 16 & $\begin{array}{l}\text { OVERALL: It looks as if 'belly feeling' is more used than LCA in the sustainable } \\
\text { choices made. SPECIFIC: } 1 \text {. There is hardly any LCA specific terminology used. } \\
\text { Explanation of the analyses or results is absent. Graphs are too small to be read. } \\
\text { 2. The reader is not taken by the hand when looking at the results. Explanation } \\
\text { of the analyses or results is absent. Graphs are too small to be read. 3. I guess } \\
\text { the LCA results hardly influenced the design, because of the simplifying choices } \\
\text { that were made during the modeling process (no cap, no band). }\end{array}$ & LCA1 & $\begin{array}{l}\text { belly feeling is more used than LCA. There is } \\
\text { hardly any LCA specific terminology used } \\
\text { and explanation of the analysis is absent. I } \\
\text { guess the LCA results hardly influenced the } \\
\text { design, because of the simplifying choices } \\
\text { that were made during the modeling process. }\end{array}$ & $\begin{array}{l}\text { belly feeling more used than } \\
\text { LCA, hardly any LCA } \\
\text { terminology, explanation is } \\
\text { absent, not taken by the hand, } \\
\text { simplifying choices during } \\
\text { process }\end{array}$ & A \\
\hline 17 & $\begin{array}{l}\text { OVERALL: Good thinking both on material selection (bio-based) and design for } \\
\text { recycling (best of all groups). Nice that the label design contains ample } \\
\text { information about the material origin and recyclability of the product. The } \\
\text { source of the bio-based material could be discussed better; there are quite } \\
\text { unfavorable or even unsustainable bio-based materials. SPECIFIC: } 1 \text {. Almost. } \\
\text { The statement "There is still no special collection system for bio plastics in the } \\
\text { Netherlands. This does not have to be a problem. It is possible to process } \\
\text { bio-plastics in the current recycling systems." is not entirely true: } \\
\text { - The group should have used the term 'bio-based plastics' } \\
\text { - bio-based PET is from a biotic resource, but has exactly the same chemical } \\
\text { properties as fossil-based PET. Therefore, the bio-PET is well suited for the } \\
\text { common recycling routes of PET. } \\
\text { So yes, there is no problem, but the explanation is not correct. 2. Yes. But the } \\
\text { discussion of results is limited. Also, I feel that the group could have added a } \\
\text { comparison with (for instance) more materials than PET alone. PET is however } \\
\text { the most relevant comparison. Also, I think showing the results with the } \\
\text { endpoint method or circular economy approach would have been beneficial for } \\
\text { the selection of bio-based PET. . It is curious that bio-based PET has a higher } \\
\text { score than virgin PET in the LCA-tool. TNOO should have a critical look at the } \\
\text { background data. I suspect land use for the bio-based materials is the culprit. } \\
\text { Also, TNO should think again about using the very outdated shadow prices as } \\
\text { weighting method for student applications. This way, students might learn that } \\
\text { virgin fossil materials are better than renewable materials of which the sourcing } \\
\text { and production process can be optimized in the future. } \\
\text { I applaud the students that they have followed their common sense and went } \\
\text { forward with bio-based materials. The reasoning is a crooked, though: "the } \\
\text { [environmental!] costs are higher (...) but bio-PET is much better for the } \\
\text { environment (...)". This is of course false interpretation of the results. } \\
\text { The students could have improved the report by stating that sourcing of the } \\
\text { bio-based material is key. The biomass should not be a food-product (such as } \\
\text { corn). }\end{array}$ & LCA2 & $\begin{array}{l}\text { good thinking both on material selection and } \\
\text { design for recycling. Nice that the label } \\
\text { design contains ample information about } \\
\text { recyclability. The source of bio-based } \\
\text { materials could be discussed better. }\end{array}$ & $\begin{array}{l}\text { good thinking, best of all } \\
\text { groups, nice, could be } \\
\text { discussed better }\end{array}$ & B \\
\hline
\end{tabular}


Table A2. Cont.

\begin{tabular}{|c|c|c|c|c|c|}
\hline Quote No. & Complete Comment and Color & Initials Perspective & Quotes (Derived from the Comments) & $\begin{array}{l}\text { Terminology (Verbs, Nouns, } \\
\text { Adiectives) }\end{array}$ & Design \\
\hline 18 & 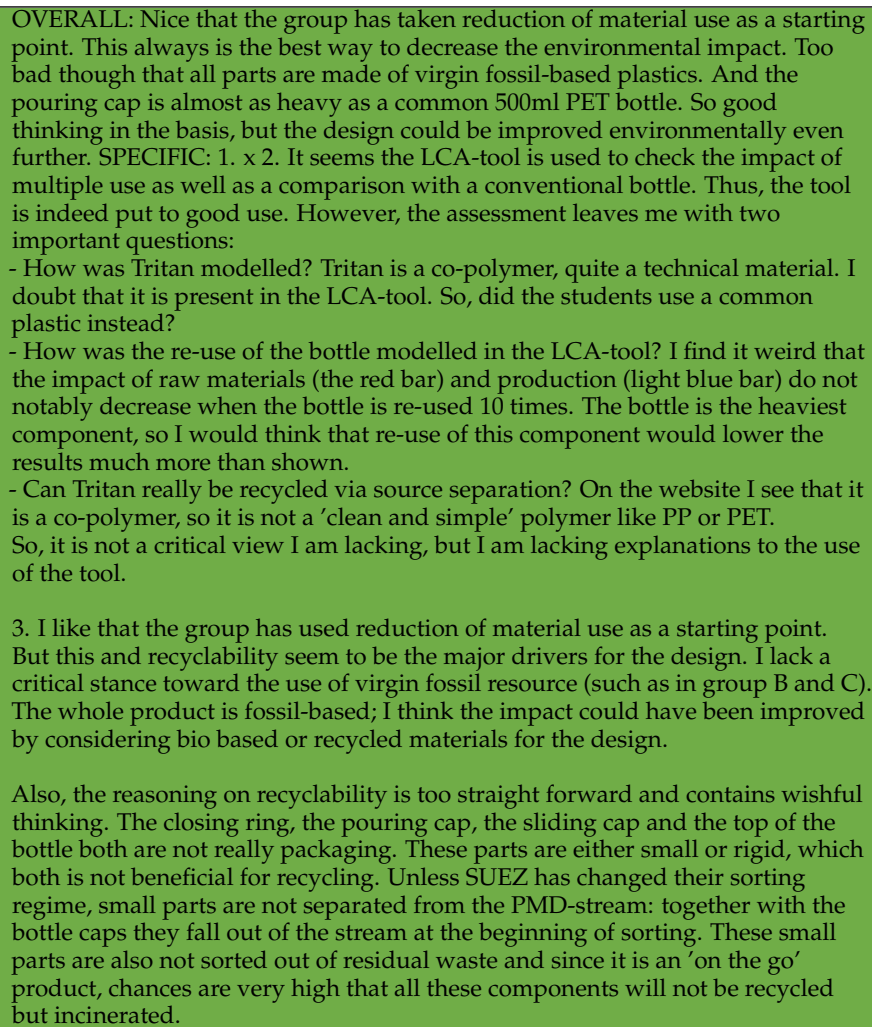 & LCA2 & $\begin{array}{l}\text { nice that the group has taken reduction of } \\
\text { material use as a starting point. This always } \\
\text { is the best way. Too bad though that all parts } \\
\text { are made out of virgin fossil-based plastics. } \\
\text { Good thinking in the basis, but design could } \\
\text { be improved. }\end{array}$ & $\begin{array}{l}\text { nice, best way, too bad } \\
\text { though, good thinking in } \\
\text { basis, could be improved }\end{array}$ & $\mathrm{D}$ \\
\hline
\end{tabular}


Table A2. Cont.

\begin{tabular}{|c|c|c|c|c|c|}
\hline Quote No. & Complete Comment and Color & Initials Perspective & Quotes (Derived from the Comments) & $\begin{array}{l}\text { Terminology (Verbs, Nouns, } \\
\text { Adjectives) }\end{array}$ & Design \\
\hline 19 & $\begin{array}{l}\text { OVERALL: The use of recycled PET as a basis is nice and the product seems } \\
\text { almost perfectly designed for recycling (just lose the stick-on label). But since } \\
\text { there is no report, the statements based on LCA-results cannot be checked. Also, } \\
\text { where would all the recycled PET come from? SPECIFIC: } 1 \text {. The terminology } \\
\text { that is used, is used correctly, but there is little to no explanation of the } \\
\text { statements. This is a pity, because the poster is quite good. } \\
\text { There is one faulty statement: "this bottle can be thrown in the trashcan and the } \\
\text { recycling scheme will do the rest". Residual waste is only separated in parts of } \\
\text { NL, where no source separation program is set up. In the case that sorting out } \\
\text { of mixed residual waste is done, not all PET bottles will in practice be sorted } \\
\text { ('nascheidingsrendement'). And then, even when a PET bottle is sorted out of } \\
\text { the residual waste, the bottle may be too contaminated to process. } \\
\text { So, especially when 'on-the-go', the bottle will be thrown in the residual waste } \\
\text { and therefore will not be automatically recycled. But since Group B made a } \\
\text { similar statement, I think this is due to misinformation during the course. I do } \\
\text { not hold this against the students. } \\
\text { 2. It seems so from the poster, but I lack visual results (graphs) and a discussion } \\
\text { of results. Information to back the statements such as 'recycled PET has the } \\
\text { lowest environmental impact' is missing. The choice for PP cap is made } \\
\text { 'because it is easiest to recycle', but this is not supported by results. 3. Unclear. } \\
\text { From the poster it becomes clear that LCA results did have an influence. But it } \\
\text { is not clear how the results have shaped the decision-making process. } \\
\text { The lack of a report with a little bit more background information is a real pity, } \\
\text { because I know that choice for rPET is environmentally OK. }\end{array}$ & LCA2 & $\begin{array}{l}\text { pet as a basis is nice, seems almost perfectly } \\
\text { designed, however statements cannot be } \\
\text { checked. }\end{array}$ & $\begin{array}{l}\text { nice, seem almost perfectly } \\
\text { designed for recycling, no } \\
\text { report, cannot be checked. }\end{array}$ & C \\
\hline 20 & $\begin{array}{l}\text { OVERALL: Both on resource selection and on recyclability, the group could } \\
\text { have been more critical. Not all design decisions are explained environmentally, } \\
\text { such as the choice for neoprene for the lid. The result is a common beverage } \\
\text { carton. } \\
\text { SPECIFIC: } 1 \text {. The poster and report contain virtually no terminology. Results } \\
\text { are displayed (not really readable) but not really discussed. On the poster it } \\
\text { says 'sustainable' twice, but it incorrectly: } \\
\text { - It is not explained why this packaging is sustainable. } \\
\text { - The origin of the paper fibres is not touched upon; the aluminium and plastic } \\
\text { layers in bev.cartons are not sustainable at all. } \\
\text { 2. Difficult to judge, since the graphs are not readible in the report. From the } \\
\text { titles and units, it seems that the graphs are created correctly. Ilack a critical } \\
\text { view on the use of beverage carton with alu foil. } \\
\text { 3. It does not become clear what the decisive reason is for selecting beverage } \\
\text { carton as a material. I see that the 'own pack' is compared with virgin } \\
\text { aluminium and virgin PET bottles. But what about bio based materials? } \\
\text { The material choice for the neoprene lid is not explained. Results of the } \\
\text { assessment with Edupack are not reported, which is an important omission in } \\
\text { the report. I doubt that a neoprene cap has a lower impact than a similar cap } \\
\text { made of common plastic, like PP or HDPE. } \\
\text { I lack a discussion and a critical view on recyclability. On the poster, it is stated } \\
\text { 'the package will be recycled' and 'recycling when possible'. But the aluminum } \\
\text { and plastic layers in the beverage cartons will not be recycled: recycling of } \\
\text { bev.cartons occurs at paper recycling plants. Also, it is an 'on-the-go' product. } \\
\text { Bev.cartons that are thrown in the residual waste, which often is the case when } \\
\text { 'on the go', will not be separated from the waste and will thus not be recycled. }\end{array}$ & LCA2 & $\begin{array}{l}\text { both on resource selection and recyclability } \\
\text { the group could have been more critical }\end{array}$ & $\begin{array}{l}\text { could have been more critical, } \\
\text { not all decisions are explained }\end{array}$ & A \\
\hline
\end{tabular}


Table A2. Cont.

\begin{tabular}{|c|c|c|c|c|c|}
\hline Quote No. & Complete Comment and Color & Initials Perspective & Quotes (Derived from the Comments) & $\begin{array}{l}\text { Terminology (Verbs, Nouns, } \\
\text { Adjectives) }\end{array}$ & Design \\
\hline 21 & $\begin{array}{l}\text { OVERALL: Not sure if the carton includes a plastic layer too (next to aluminium } \\
\text { [poster]; report says no Al-layer??): is the neoprene band only a seal? LCA } \\
\text { report: only a carton layer. This will not meet the functional requirements! } \\
\text { SPECIFIC: } 1 . x 2 . x\end{array}$ & LCA3 & $\begin{array}{l}\text { not sure if the carton includes a plastic layer, } \\
\text { report says no, will not meet functional req. }\end{array}$ & $\begin{array}{l}\text { not sure, will not meet } \\
\text { functional requirements }\end{array}$ & A \\
\hline 22 & $\begin{array}{l}\text { OVERALL: The main positive aspect of this design is that it takes into account } \\
\text { the relationship product-packaging. In the moment of choice, transportation, } \\
\text { storage until the moment of consumption the product and the packaging are } \\
\text { considered combined, as an overall so it is important to take into account the } \\
\text { product-packaging combination, as did in this design. The sustainability of the } \\
\text { packaging is also clearly communicated to the consumers that understand the } \\
\text { reusability of the bottle. The originality also attracts the consumers that are } \\
\text { willing to try it. SPECIFIC } 1 \text {. The idea is original and explained in lots of details. } \\
\text { Sustainability will be clearly perceived as well as convenience. } 2 . x\end{array}$ & СРB1 & $\begin{array}{l}\text { The sustainability of the packaging is also } \\
\text { clearly communicated to the consumers that } \\
\text { understand the reusability of the bottle. } \\
\text { Sustainability will be clearly perceived as } \\
\text { well as convenience. }\end{array}$ & $\begin{array}{l}\text { main positive aspect, takes } \\
\text { into account, clearly } \\
\text { communicated, attracts, } \\
\text { explained in lot of details, } \\
\text { sustainability will be clearly } \\
\text { perceived }\end{array}$ & D \\
\hline 23 & $\begin{array}{l}\text { OVERALL: The positive aspect of this design is that the sustainability is clearly } \\
\text { communicated to the consumer that is aware of that in the moment of choice. } \\
\text { Moreover, the green color of the lid is an effective cue in evoking the benefit of } \\
\text { sustainability. In the label there is a representation of the product that will form } \\
\text { expectations about the content to consumers. So, consumers will make } \\
\text { inferences about the product from the packaging design. Labels and } \\
\text { information on the bio-based bottle communicate the sustainability and the } \\
\text { original shape attract the consumer. } \\
\text { SPECIFIC: } 1 \text {. Good link packaging cues-consumers perception. Examples are } \\
\text { provided and explained in a convincing way. Sustainability is communicated as } \\
\text { well as convenience. } 2 \text {. In general I consider the report a good and complete } \\
\text { tool to understand the packaging design. }\end{array}$ & СРВ1 & $\begin{array}{l}\text { positive aspect of this design is that the } \\
\text { sustainability is clearly communicated to the } \\
\text { consumer. Moreover, the green color of the } \\
\text { lid is an effective cure. Labels and } \\
\text { information on the bio-based bottle } \\
\text { communicate the sustainability and the } \\
\text { original shape attract the consumer }\end{array}$ & $\begin{array}{l}\text { positive, clearly } \\
\text { communicated, effective cue, } \\
\text { good link packaging cues - } \\
\text { consumer perception, } \\
\text { examples are provided and } \\
\text { explained, Good report. }\end{array}$ & B \\
\hline 24 & $\begin{array}{l}\text { OVERALL: Through the cue of the packaging the consumers will perceive the } \\
\text { naturalness of the product and the packaging, this represent a positive aspect of } \\
\text { this design. Little information is provided to consumers (little label) so the link } \\
\text { with the product and consequently the mental categorization are not taken into } \\
\text { account. The convenience also tradeoff with sustainability in this case. In the } \\
\text { mind of consumers an increase in sustainability is perceived as a decrease in } \\
\text { convenience. In this design with the strange shape this is the risk. SPECIFIC: } 1 \text {. } \\
\text { The assessment of this design is limited to the poster, so not comparable with } \\
\text { the other designs. } 2 . x\end{array}$ & СРB1 & $\begin{array}{l}\text { consumers will perceive the naturalness of } \\
\text { the product, however little information are } \\
\text { provided to consumers, so the link with the } \\
\text { mental categorization are not taken into } \\
\text { account. Decrease in convenience }\end{array}$ & $\begin{array}{l}\text { Little information, not taken } \\
\text { into account, decrease in } \\
\text { convenience, assessment is } \\
\text { limited to poster, not } \\
\text { comparable }\end{array}$ & C \\
\hline
\end{tabular}


Table A2. Cont.

\begin{tabular}{|c|c|c|c|c|c|c|}
\hline Quote No. & \multirow[b]{2}{*}{$\begin{array}{l}\text { Complete Comment and Color } \\
\text { OVERALL: The choice of the material (paper) is the only aspect that makes this } \\
\text { packaging perceived as sustainable. The sustainability is indeed not really } \\
\text { communicated to consumers with other packaging cues, except by the material. } \\
\text { The tradeoff between sustainability and attractiveness is also not really well } \\
\text { balanced. For many consumers sustainability is not an important benefit for } \\
\text { their choice, so the design should also be attractive and stands out from the } \\
\text { shelf of the store (trigger the attention). Moreover, no link with the product } \\
\text { content is made so consumers will have difficulties in categorizing the } \\
\text { product-packaging combinations since the packaging cues do not form any } \\
\text { expectations. How consumers will recognize the healthy alternative to soft } \\
\text { drink from the packaging? Remember that the packaging is also called the } \\
\text { "silent salesman". SPECIIC: } 1 \text {. The integration of the results from the survey in } \\
\text { the packaging design is mostly done and correct. Sometimes the line of } \\
\text { reasoning would require more details and analytical insights. } 2 \text {. the reasoning is } \\
\text { clear but some aspects of the survey are not taken into account in the design } \\
\text { (convenience covered by the question } 2 \text { and } 5 \text { suggests that some improvements } \\
\text { could be made in the design). }\end{array}$} & \multirow[b]{2}{*}{$\begin{array}{l}\text { Initials Perspective } \\
\text { CPB1 }\end{array}$} & \multicolumn{2}{|c|}{ Quotes (Derived from the Comments) } & \multirow[b]{2}{*}{$\begin{array}{l}\text { Terminology (Verbs, Nouns, } \\
\text { Adjectives) } \\
\\
\text { ity not really communicated, } \\
\text { ulties in categorizing, do not } \\
\text { Integration of results is done } \\
\text { soning require more details, } \\
\text { ount, }\end{array}$} & \multirow[b]{2}{*}{$\begin{array}{l}\text { Design } \\
\\
\text { A }\end{array}$} \\
\hline 25 & & & $\begin{array}{l}\text { the sustainability is } \\
\text { indeed not really } \\
\text { communicated with } \\
\text { other packaging } \\
\text { cues, except by } \\
\text { material. Tradeoff } \\
\text { between } \\
\text { sustainability \& } \\
\text { attractiveness is also } \\
\text { not well balanced. }\end{array}$ & $\begin{array}{l} \\
\text { only aspect, sustainability not really communicated, } \\
\text { not well balanced, difficulties in categorizing, do not } \\
\text { form any expectations. Integration of results is done } \\
\text { and correct, Line of reasoning require more details, } \\
\text { clear, not taken into account, }\end{array}$ & & \\
\hline 26 & $\begin{array}{l}\text { OVERALL: best consumer-oriented co-creation efforts. SPECIFIC } 1 \text {. Students } \\
\text { did vary quite well the design features to figure out how single features will } \\
\text { contribute to consumer perception. Students took the insights they gained to } \\
\text { decide on final design features to increase perceived sustainability. However, } \\
\text { features do not vary systematically (no experimental design with all possible } \\
\text { combinations) \& some conclusions should not be made; for instance, it cannot } \\
\text { be concluded which of the features increases (perceived) recyclability, as e.g., } \\
\text { done for "label without glue". Likely the additional recycling logo on the lid is } \\
\text { largely responsible for higher ratings for bottle } 3 \text { in qu. } 1 \text { and } 4 \text {, and the glueless } \\
\text { label might not make a difference. Also, all bottles have the recycling logo not } \\
\text { he bottles, so why conclude an effect for this feature? } 2 \text { students took insights } \\
\text { into account for the final design to be perceived more sustainable. As they } \\
\text { found that the plant imprint as well as a green lid was perceived more } \\
\text { sustainable, they implemented these features. They also implemented the } \\
\text { features, they found to be affecting recycling behavior and thus supports the } \\
\text { more sustainable end-life-option. However, the conclusion mainly states the } \\
\text { interpretation of results, and more elaboration on conclusions for the design } \\
\text { could have been provided in the text. }\end{array}$ & СРB2 & \multicolumn{2}{|c|}{$\begin{array}{l}\text { best consumer oriented, students took } \\
\text { insights into account for the final design to be } \\
\text { perceived more sustainable. However, the } \\
\text { conclusion mainly states the interpretation of } \\
\text { results, and more elaboration on conclusions } \\
\text { for the design could have been provided. }\end{array}$} & $\begin{array}{l}\text { best consumer oriented, vary } \\
\text { quite well, contribute to } \\
\text { consumer perception, took } \\
\text { the insights, do not vary } \\
\text { systematically, some } \\
\text { conclusion should not be } \\
\text { made, took insights into } \\
\text { account, they implemented } \\
\text { these features, more } \\
\text { elaboration could have been } \\
\text { provided }\end{array}$ & B \\
\hline
\end{tabular}


Table A2. Cont.

\begin{tabular}{|c|c|c|c|c|c|}
\hline Quote No. & Complete Comment and Color & Initials Perspective & Quotes (Derived from the Comments) & $\begin{array}{l}\text { Terminology (Verbs, Nouns, } \\
\text { Adjectives) }\end{array}$ & Design \\
\hline 27 & $\begin{array}{l}\text { OVERALL: material used is perceived as sustainable, could more use insights in } \\
\text { determining the final design. SPECIFIC: } 1 \text {. Students did take into account } \\
\text { asking how potential customers view their design. However, features of interest } \\
\text { could have been varied more systematically between designs shown, to be able } \\
\text { to relate answers to features. It would have been advised to standardize } \\
\text { alternatives more regarding features not of interest, e.g., info given on the pack } \\
\text { (as brand, name product etc.) as well as content (e.g., not water vs juice) (e.g., } \\
\text { asking to disregard brand or color seems less helpful, as this will not be possible, } \\
\text { as it (unconsciously) will have an influence anyway).2. insights could have been } \\
\text { used more critically to give input for a possible redesign (e.g., regarding the lid } \\
\text { as people were not sure about performance here). In the discussion Students } \\
\text { summarize insights, state it is important that sustainable products are bought } \\
\text { and then argue for their design. However little connection is made from } \\
\text { insights to final design, rather it is argued to keep the initial design, e.g., as it is } \\
\text { more sustainable than with plastic cap, even though consumers do not really } \\
\text { acknowledge this difference (table 2 Qu. 1) or care about it (part 2, qu.3) }\end{array}$ & СРB2 & $\begin{array}{l}\text { material used is perceived as sustainable, } \\
\text { could more use insights in determining the } \\
\text { final design. Students did take into account } \\
\text { how potential customers view their design. } \\
\text { However, insights could have been used } \\
\text { more critically. However little connection is } \\
\text { made from insights to final design. }\end{array}$ & $\begin{array}{l}\text { could use more insights, did } \\
\text { not take into account, could } \\
\text { have been varied more, could } \\
\text { have been sed more critically, } \\
\text { summarize insights, state } \\
\text { importance, little connection } \\
\text { is made from insights to final. }\end{array}$ & A \\
\hline 28 & $\begin{array}{l}\text { OVERALL: nice idea, insufficient description of consumer insights and } \\
\text { respective reasoning for final design. SPECIFIC: } 1 \text {. Students took into account } \\
\text { that many people preferred the white colored design. However, description } \\
\text { lacks a lot of information. Report of the alternatives (as e.g., on poster) given to } \\
\text { consumers is poor and thus hard to reconstruct the decision made. } \\
\text { Besides color, it is mentioned that the (working) system is most important to be } \\
\text { clear, but no info on experimental/question design and results regarding this } \\
\text { crucial feature could be found! } 2 \text {. Information provided on the conducted } \\
\text { consumer study is insufficient. Only color is taken into account. Reported } \\
\text { design and results are lacking crucial information needed to judge further } \\
\text { influence on design. }\end{array}$ & СРB2 & $\begin{array}{l}\text { nice idea, insufficient description and } \\
\text { respective reasoning final design. Students } \\
\text { took into account that many people preferred } \\
\text { the with colored design, however description } \\
\text { lacks information. Reported design and } \\
\text { results lacking crucial information to judge } \\
\text { further influence on the design. }\end{array}$ & $\begin{array}{l}\text { nice idea, insufficient } \\
\text { description and reasoning, } \\
\text { took into account, however } \\
\text { lacks information, } \\
\text { information provided is } \\
\text { insufficient, lacking crucial } \\
\text { information. }\end{array}$ & D \\
\hline 29 & $\begin{array}{l}\text { OVERALL: little info provided, no apparent consumer co-creation. SPECIFIC: } 1 . \\
\text { no report; based on poster students did not include a focus group or similar } \\
\text { consumer technique in their developmental process and so did not involve the } \\
\text { actual consumer int he design process. The label is recycled paper to increase } \\
\text { sustainability perceived, however, this label is neglectable compared to the } \\
\text { main plastic body which sustainable material is apparently not communicated } \\
\text { to consumers. 2. no report; again, the only thing described is the choice of the } \\
\text { label material with regard to perceived sustainability; "we keep the shape of a } \\
\text { bottle" is fine but not really taking perception revolving sustainability or } \\
\text { convenience into account }\end{array}$ & СРB2 & $\begin{array}{l}\text { little info provided, no apparent consumer } \\
\text { co-creation. Did not include a focus group. } \\
\text { The label is recycled paper to increase } \\
\text { sustainability perceived, however this label is } \\
\text { neglectable compared to the main plastic } \\
\text { body which sustainable material is } \\
\text { apparently not communicated to consumers. }\end{array}$ & $\begin{array}{l}\text { little info provided, no } \\
\text { consumer co creation, did not } \\
\text { include, did not involve the } \\
\text { actual consumer, label is } \\
\text { neglectable compared to main } \\
\text { body, not communicated to } \\
\text { consumers, no report, not } \\
\text { really taking into account }\end{array}$ & C \\
\hline 30 & $\begin{array}{l}\text { OVERALL: Report is missing. Nice design with clear and convincing } \\
\text { justifications in the poster. SPECIFIC: } 1 . \times 2 \cdot x\end{array}$ & СРВ3 & $\begin{array}{l}\text { nice design with clear and convincing } \\
\text { justifications }\end{array}$ & $\begin{array}{l}\text { nice, clear and convincing } \\
\text { justifications }\end{array}$ & $\mathrm{C}$ \\
\hline
\end{tabular}


Table A2. Cont.

\begin{tabular}{|c|c|c|c|c|c|}
\hline Quote No. & Complete Comment and Color & Initials Perspective & Quotes (Derived from the Comments) & $\begin{array}{l}\text { Terminology (Verbs, Nouns, } \\
\text { Adjectives) }\end{array}$ & Design \\
\hline 31 & $\begin{array}{l}\text { OVERALL: Nice try. The sustainable look may influence people to buy the } \\
\text { bottle but there are some information missing (e.g., quantity, type of juice } \ldots \text { ). } \\
\text { It is also unclear how people will manage to drink the juice on the go in a } \\
\text { convenient way. SPECIFIC: } 1 . \times 2 . x\end{array}$ & СВР3 & $\begin{array}{l}\text { nice try, sustainable look may influence } \\
\text { people to buy the bottle, however it is unclear } \\
\text { how people will manage to drink the juice on } \\
\text { the go in a convenient way. }\end{array}$ & $\begin{array}{l}\text { nice try, may influence, some } \\
\text { information missing, unclear } \\
\text { how }\end{array}$ & A \\
\hline 32 & $\begin{array}{l}\text { OVERALL: Pretty design, nice label with a lot of information regarding } \\
\text { sustainability. Bio-based is not always considered a more sustainable alternative } \\
\text { by consumers. Also, the appearance of the bottle (shiny thick plastic) does not } \\
\text { denote sustainability. SPECIFIC: } 1 . \times 2 . x\end{array}$ & СВР3 & $\begin{array}{l}\text { Pretty design, nice label with a lot of info } \\
\text { regarding sustainability. However, the } \\
\text { appearance of the bottle (shiny thick plastic) } \\
\text { does not denote sustainability }\end{array}$ & $\begin{array}{l}\text { pretty, lot of information } \\
\text { regarding sustainability, } \\
\text { appearance does not denote } \\
\text { sustainability }\end{array}$ & B \\
\hline 33 & $\begin{array}{l}\text { OVERALL: It is not an on the go bottle (you have to wash it before you use it). It } \\
\text { is likely that the concentrates will not be considered as healthy options by } \\
\text { consumers. The design is pretty, and it is true that it is truly more sustainable to } \\
\text { sell an empty bottle. However, consumers might not perceive it as such. } \\
\text { SPECIFIC: } 1 . \times 2 . x\end{array}$ & СВР3 & $\begin{array}{l}\text { the design is pretty, and it is true that it is } \\
\text { truly more sustainable to sell an empty bottle, } \\
\text { however, consumers might not perceive it } \\
\text { as such. }\end{array}$ & $\begin{array}{l}\text { not, not be considered as } \\
\text { healthy, design is pretty, is } \\
\text { truly more sustainable, } \\
\text { however consumers might } \\
\text { not perceive }\end{array}$ & D \\
\hline 34 & $\begin{array}{l}\text { OVERALL: The concept is promising and has much potential from viewpoint of } \\
\text { sustainability SPECIFIC } 1 \text {. The concept shows possible savings without } \\
\text { knowing about the packaging details. Therefore, this design is great. The } \\
\text { explanation is limited and can be better. A critical reflection is missing. } 2 \text {. The } \\
\text { roles are not explained in the report although the approach was wide, as the } \\
\text { topics that have been taken up show. A reflection is missing. }\end{array}$ & MDD1 & $\begin{array}{l}\text { the concept is promising and has much } \\
\text { potential from viewpoint of sustainability, } \\
\text { however the explanation is limited and can } \\
\text { be better. A critical reflection is missing. }\end{array}$ & $\begin{array}{l}\text { Promising, potential, possible } \\
\text { savings, design is great, } \\
\text { explanation is limited, critical } \\
\text { reflection is missing }\end{array}$ & D \\
\hline 35 & $\begin{array}{l}\text { OVERALL: Approach looks rather ok. Clear choices. Question is if bio-PET and } \\
\text { bio-PE are more sustainable and if they are not solutions based on food sources. } \\
\text { How about the label? This is not clear. SPECIFIC: } 1 \text {. Clear choices made on base } \\
\text { of insights in the chain and by using the tool properly. } 2 \text {. The roles were } \\
\text { explained in the beginning of the report very well. It looks like the roles made } \\
\text { making choices more rational. }\end{array}$ & MDD1 & $\begin{array}{l}\text { approach looks rather ok, clear choices, } \\
\text { question is if bio pet and bio PE are more } \\
\text { sustainable. }\end{array}$ & $\begin{array}{l}\text { looks rather ok, clear choices, } \\
\text { based on insights, question is } \\
\text { if, this is not clear, using tool } \\
\text { properly }\end{array}$ & B \\
\hline 36 & $\begin{array}{l}\text { OVERALL: Approach looks good, but it is not easy to get rPET for bottles } \\
\text { although there are developments going on. The company has to be active to be } \\
\text { sure to get food-safe rPET. The honeycomb will not save much space, is it? } \\
\text { SPECIFIC: } 1 \text {. No report, only a poster. } \\
\text { Choices have been made about many issues. The explanation is very limited. } 2 \text {. } \\
\text { The roles are not explained at the poster. }\end{array}$ & MDD1 & $\begin{array}{l}\text { approach looks good, but it is not easy to get } \\
\text { rPET for bottles. The explanation is very } \\
\text { limited }\end{array}$ & $\begin{array}{l}\text { approach looks good, no } \\
\text { report, explanation very } \\
\text { limited, are not explained }\end{array}$ & C \\
\hline 37 & $\begin{array}{l}\text { OVERALL: What are the gains? It is still a beverage carton. The cap is replaced } \\
\text { by neoprene, not a very sustainable plastic. Carton appearance looks } \\
\text { sustainable. SPECIFIC:1. Sustainability issues are taken up isolated from the } \\
\text { role they play in the chain, from the environmental load in the chain and } \\
\text { without looking at the product-packaging combination (taking out aluminum } \\
\text { would mean that the shelf life is gone, and product loss can increase). Because } \\
\text { of a lack of a wide approach the design is not very good. } 2 \text {. The topics are taken } \\
\text { up very isolated. They tried to integrate them, but they did not succeed in this. } \\
\text { The report is a process description on a level that does not give insight in the } \\
\text { ration behind the choices, but more in the thoughts of the participants }\end{array}$ & MDD1 & $\begin{array}{l}\text { because of the lack of a wide approach the } \\
\text { design is not very good. They tried to } \\
\text { integrate topics, but they did not succeed in } \\
\text { this. (The report is a process description on a } \\
\text { level that does not give insight in the ration } \\
\text { behind the choices, but more in the thoughts } \\
\text { of the participants) }\end{array}$ & $\begin{array}{l}\text { still, lack of approach, design } \\
\text { is not very good, did not } \\
\text { succeed, level that does not } \\
\text { give insight in choices. }\end{array}$ & A \\
\hline
\end{tabular}


Table A2. Cont.

\begin{tabular}{|c|c|c|c|c|c|}
\hline Quote No. & Complete Comment and Color & Initials Perspective & Quotes (Derived from the Comments) & $\begin{array}{l}\text { Terminology (Verbs, Nouns, } \\
\text { Adjectives) }\end{array}$ & Design \\
\hline 38 & $\begin{array}{l}\text { OVERALL: Overall description and justification the best. Nice solution } \\
\text { direction, concentrating the core product. However, not a new direction, your } \\
\text { main competitor immediately becomes Karvan Cevitam. And their concept is } \\
\text { better suited for on-the-go. The traditional cups with seal do not seem tailored } \\
\text { towards this use scenario. As far as sustainability goes: the overall assumption } \\
\text { (implicitly made?) seems to be that a refillable drinking bottle is more } \\
\text { sustainable than pet-variants of for instance Spa? Potentially problematic: a } \\
\text { drinking bottle is not part of the portfolio of a (on-the-go) supermarket. } \\
\text { SPECIFIC: } 1 \text {. Concepts! Analysis! A design brief! You're the first to do that! } \\
\text { Good introduction! A short but solid overall design justification. What I mis is } \\
\text { the transition of the concepts and the final design. Why was concept } 1 \text { chosen? } \\
\text { You could use the requirements for such an assessment. 2. You seem to have } \\
\text { done it (table on page } 7 \text { lists the roles) but there is no description, no } \\
\text { consequences. }\end{array}$ & MDD2 & $\begin{array}{l}\text { Overall description and justification the best. } \\
\text { Nice solution, concentrating the core product, } \\
\text { however not a new direction (traditional cups } \\
\text { with seal do not seem tailored towards use } \\
\text { scenario). }\end{array}$ & $\begin{array}{l}\text { justification the best, nice } \\
\text { solution, not a new direction, } \\
\text { potentially problematic, good, } \\
\text { solid overall design } \\
\text { justification, miss, }\end{array}$ & D \\
\hline 39 & $\begin{array}{l}\text { OVERALL: Best on different disciplines. Marketing-wise a nice touch } \\
\text { incorporating the logo in the shape. Does come with engineering challenges. } \\
\text { Sustainable justification choices are current way of working. It does not } \\
\text { communicate sustainability. SPECIFIC: } 1 \text {. Choices and considerations are listed. } \\
\text { There is no chain of reasoning, no concept description, no trade-offs, no } \\
\text { interrelations. } 2 \text {. Nice overall description of the different roles/ perspectives. } \\
\text { No follow-through on the actual usage in the design process, and linkage to the } \\
\text { concept, for instance via requirements is absent. }\end{array}$ & MDD2 & $\begin{array}{l}\text { Best on different disciplines. Sustainable } \\
\text { justification choices are current way of } \\
\text { working. Choices and considerations are } \\
\text { listed, however there is no chain of reasoning. }\end{array}$ & $\begin{array}{l}\text { best on different disciplines, } \\
\text { not communicate } \\
\text { sustainability, no chain of } \\
\text { reasoning, no tradeoffs, nice } \\
\text { overall description, no follow } \\
\text { through, absent }\end{array}$ & B \\
\hline 40 & $\begin{array}{l}\text { OVERALL: Weak, closure aspect seems a nice addition but is not explained. Not } \\
\text { new, only the cap seems a new addition? Not much content on the poster. } \\
\text { Concept not suitable for on the go, no branding, might be a deliberate decision } \\
\text { but there is no justification for that. Design tool is a process description instead } \\
\text { of design justification. SPECIFIC: } 1 \text {. The justification is mostly a process } \\
\text { description of what you've done. As a designer I'm interested in the } \\
\text { justification of the final design. There is no total concept description, no } \\
\text { justification of choices. Why the strong focus on the closure? The weight alone } \\
\text { of the cardboard is reason enough to consider it. You seem to choose a standard } \\
\text { multi-layer for your pack: why? What justifies the use of aluminum in this? } \\
\text { There is no justification on the appearance, the layout. The different } \\
\text { perspectives for the closure are a nice aspect, these aspects read as requirements, } \\
\text { which are an indispensable aspect in evaluating design concepts. } 2 \text {. For the } \\
\text { closure, nicely done. For the rest, and more strategic choices: absent. }\end{array}$ & MDD2 & $\begin{array}{l}\text { Weak, closure seems a nice addition but is not } \\
\text { explained. Justification is mostly a process } \\
\text { description, as a designer I am interested in } \\
\text { the justification of the final design (why a } \\
\text { strong focus on the closure) }\end{array}$ & $\begin{array}{l}\text { weak, not explained, not new, } \\
\text { no justification of choices }\end{array}$ & A \\
\hline 41 & $\begin{array}{l}\text { OVERALL: Promising poster but no justification and content. Complete design } \\
\text { proposal on poster. Shape with sharp corners is challenging. The honeycomb is } \\
\text { a nice touch, but it interferes with the main category: drinks. Sustainable } \\
\text { direction strongest of the four groups. SPECIFIC } 1 \text {. report not available, based } \\
\text { on poster: no. 2. Report not available, based on poster: no }\end{array}$ & MDD2 & $\begin{array}{l}\text { Promising poster, but no justification. Shape } \\
\text { with sharp corners is challenging. Sustainable } \\
\text { direction strongest of the four groups. }\end{array}$ & $\begin{array}{l}\text { Promising, no justification, } \\
\text { challenging, nice, interferes }\end{array}$ & C \\
\hline
\end{tabular}


Table A2. Cont.

\begin{tabular}{|c|c|c|c|c|c|}
\hline Quote No. & Complete Comment and Color & Initials Perspective & Quotes (Derived from the Comments) & $\begin{array}{l}\text { Terminology (Verbs, Nouns, } \\
\text { Adjectives) }\end{array}$ & Design \\
\hline 42 & $\begin{array}{l}\text { OVERALL: Design fits with the brand, the reuse aspect is taken into account in } \\
\text { the material usage. Although it doesn't do any good for the recycling (tritan } \\
\text { PC). Bit of a copycat (Dopper), but added a nice touch with the logo and cap } \\
\text { with syrup. The artwork cardboard is not a label with adhesive, which makes it } \\
\text { easy to remove. But is it still a packaging? Or is it a product? It is a round } \\
\text { packaging/product, which fits in the existing packaging portfolio of Zonnatua. } \\
\text { Also, the artwork meets the looks. SPECIFIC: } 1 . x 2 . x\end{array}$ & MDD3 & $\begin{array}{l}\text { Design fits the brand; the reuse aspect is } \\
\text { taken into account in the material usage. } \\
\text { Although it doesn't do any good for the } \\
\text { recycling (tritan PC). Artwork cardboard is } \\
\text { not a label with adhesive, which makes it } \\
\text { easy to remove. However bit of a copycat } \\
\text { (Dopper), is it still a packaging or is it a } \\
\text { product }\end{array}$ & $\begin{array}{l}\text { fits, considered, doesn't do } \\
\text { any good, copycat, nice touch, } \\
\text { easy to, is it still a packaging, } \\
\text { meets the looks }\end{array}$ & $\mathrm{D}$ \\
\hline 43 & $\begin{array}{l}\text { OVERALL: Nice look, and good thoughts about the material usage and } \\
\text { communication towards consumer. But doesn't seem to fit in the current } \\
\text { packaging portfolio of Zonnatura. The shape of the logo is taken over in the } \\
\text { bottle, which I like. But it takes more material to make the bottle square, which } \\
\text { is unnecessary, taken in account Zonnatura wants to lower the environmental } \\
\text { impact. The material is very transparent, so it will be hard to apply recycled } \\
\text { content in the bottle. Most of the packaging (containers and bottles) of } \\
\text { Zonnatura are round shaped instead of square shaped. This packaging doesn't } \\
\text { fit with the existing packaging portfolio. They communicate very clearly about } \\
\text { the recyclability of the bottle, to influence and inform the consumer about what } \\
\text { to do with the bottle after usage. SPECIFIC: } 1 \text {. the report is missing the critical } \\
\text { reflection on their design. } 2 . x\end{array}$ & MDD3 & $\begin{array}{l}\text { Nice look and good thoughts about the } \\
\text { material usage and communication towards } \\
\text { consumers, however, does not seem to fit in } \\
\text { the current packaging portfolio of Zonnatura. } \\
\text { They communicate very clearly about the } \\
\text { recyclability of the bottle, to influence and } \\
\text { inform the consumer about what to doe with } \\
\text { the bottle after usage. Report is missing the } \\
\text { critical reflection on their design. }\end{array}$ & $\begin{array}{l}\text { nice look, good thoughts, } \\
\text { doesn't seem to fit, } \\
\text { communicate very clear about } \\
\text { recyclability, missing critical } \\
\text { reflection, takes more } \\
\text { material, }\end{array}$ & B \\
\hline 44 & $\begin{array}{l}\text { OVERALL: Nice look, and good thoughts about the material usage and } \\
\text { communication towards consumer. But doesn't seem to fit in the current } \\
\text { packaging portfolio of Zonnatura. Ilike the added structure for extra strength / } \\
\text { less material usage. They took an structure which comes from nature. That fits } \\
\text { in the Zonnatura brand. But alike packaging B: It takes more material to make } \\
\text { the bottle square, which is unnecessary, taken in account Zonnatura want the } \\
\text { packaging to be low in environmental impact. It is very transparent, so it will be } \\
\text { hard to apply recycled content in the bottle. Most of the packaging (containers } \\
\text { and bottles) are round shaped instead of square. So it doesn't fit with the } \\
\text { existing packaging portfolio. SPECIFIC: } 1 \text {. x 2. x }\end{array}$ & MDD3 & $\begin{array}{l}\text { Nice look and good thoughts about the } \\
\text { material usage. However it takes more } \\
\text { material to make the bottle square, which is } \\
\text { unnecesary. It is very transparant, so it will be } \\
\text { hard to apply recycled content in the bottle. }\end{array}$ & $\begin{array}{l}\text { nice look, good thoughts, } \\
\text { doesn't seem to fit, Ilike, } \\
\text { takes more material, does not } \\
\text { fit }\end{array}$ & C \\
\hline 45 & $\begin{array}{l}\text { OVERALL: Did not take in account properly the packaging needs to be } \\
\text { resealable and watertight. And there is used a lot of unnecessary material for } \\
\text { this product. the report is poor in explanations. I don't recognize the artwork } \\
\text { similarity to existing packaging of Zonnatura. } \\
\text { Square, not watertight which is not convenient for on-the-go. Nonlogical } \\
\text { material choice (usage of cardboard). Most of the packaging (containers and } \\
\text { bottles) are round shaped instead of square. So, it doesn't fit with the existing } \\
\text { packaging portfolio. SPECIIIC: } 1 \text {. No overview of the in-between results of the } \\
\text { design process. 2. The conclusions of all the considerations are missing }\end{array}$ & MDD3 & $\begin{array}{l}\text { Did not take into account the packaging } \\
\text { needs to be resealable and water tight and } \\
\text { there is used a lot of unnecessary material. } \\
\text { Nonlogical material choice (usage of } \\
\text { cardboard) and form, most of the packaging } \\
\text { are round shaped instead of square }\end{array}$ & $\begin{array}{l}\text { did not take into account } \\
\text { properly, lot of unnecessary } \\
\text { material, poor in explanation, } \\
\text { conclusions are missing, } \\
\text { Nonlogical material choice }\end{array}$ & A \\
\hline
\end{tabular}


Table A2. Cont.

\begin{tabular}{|c|c|c|c|c|c|}
\hline Quote No. & Complete Comment and Color & Initials Perspective & Quotes (Derived from the Comments) & $\begin{array}{l}\text { Terminology (Verbs, Nouns, } \\
\text { Adjectives) }\end{array}$ & Design \\
\hline 46 & $\begin{array}{l}\text { OVERALL: Simple design, very effective for recycling. } \\
\text { SPECIFIC: } 1 \text {. Very limited text, but conclusion is correct. Not sure if they are } \\
\text { lucky with this or that this is a truly educated analysis. } 2 \text {. Basically, they choose } \\
\text { a simple material combination, commonly used in the market. The effect of } \\
\text { out-door-usage (and thus limited collection) has not been taken into account. } \\
\text { Alternatives (liked drinking cardboard) have not been assessed. }\end{array}$ & PRC1 & $\begin{array}{l}\text { Simple design, very effective for recycling. } \\
\text { Very limited text, but conclusion is correct, } \\
\text { not sure if they are lucky with this or that this } \\
\text { is a truly educated analysis. }\end{array}$ & $\begin{array}{l}\text { simple, very effective for } \\
\text { recycling, limited, correct, not } \\
\text { sure if they are lucky or a } \\
\text { truly educated analysis, have } \\
\text { not been assessed. }\end{array}$ & C \\
\hline 47 & $\begin{array}{l}\text { OVERALL: Well thought of out-door-usage. Some issues in recycling though. } \\
\text { SPECIFIC: } 1 \text {. They consider the out-of-home-usage much better than the other } \\
\text { groups. The use of small parts could be an issue in sorting. The biggest part is } \\
\text { made from tritan. This will not be recycled as it will not be recognized by our } \\
\text { sorting installation or it will be taken out by the recyclers to prevent pollution. } 2 \text {. } \\
\text { They have made re-use more important than recycling, which is good, } \\
\text { especially for out-of-home-usage. }\end{array}$ & PRC1 & $\begin{array}{l}\text { Well thought of outdoor usage, some issues } \\
\text { in recycling though. Use of small parts could } \\
\text { be an issue in sorting. The biggest part (tritan) } \\
\text { will not be recycled. They have made re-use } \\
\text { more important than recycling, which is } \\
\text { good, especially for out of home usage. }\end{array}$ & $\begin{array}{l}\text { well thought off, some issues, } \\
\text { could be an issue, not be } \\
\text { recycled and recognized }\end{array}$ & D \\
\hline 48 & $\begin{array}{l}\text { OVERALL: Good design, but too much material and no use of recycled plastics. } \\
\text { SPECIFIC: } 1 \text {. They assume that when the material is going in the residual waste, } \\
\text { it will end up in the sorting just as it would when putting it in the PMD. This is } \\
\text { not correct, and especially for out-of-home-products essential to understand. } 2 \text {. } \\
\text { Why did they not suggest the usage of recycled PET over bio-PET? The biggest } \\
\text { issue (out-of-home-usage) is underestimated. This has a big influence on the } \\
\text { recyclability and hence the design. Alternatives (drinking cardboard?) has not } \\
\text { been considered. Not sure if they have thought about laser-printing on the } \\
\text { bottle instead of additional material (cardboard sleeve). }\end{array}$ & PRC1 & $\begin{array}{l}\text { Good design, but too much material and no } \\
\text { use of recycled plastics. The biggest issue } \\
\text { (out of home usage) is underestimated, this } \\
\text { has a big influence on the recyclability and } \\
\text { hence the design. }\end{array}$ & $\begin{array}{l}\text { good design, too much } \\
\text { material, no use of recycled } \\
\text { plastics, assume, not correct, } \\
\text { essential to understand, not } \\
\text { suggest, biggest issue is } \\
\text { underestimated (out of home } \\
\text { usage), has not been } \\
\text { considered. }\end{array}$ & B \\
\hline 49 & $\begin{array}{l}\text { OVERALL: Could work, but not with neoprene. } \\
\text { SPECIFIC: } 1 \text {. Clear understanding of most of the issues in the recycling chain of } \\
\text { drinking cardboards. } \\
\text { However, recyclers will not be too happy with the usage of neoprene as this } \\
\text { might end up in the plastic-recycling and block extrusion lines and/or influence } \\
\text { the quality of the recyclate. } 2 \text {. Not clearly explained how the decision for a } \\
\text { drinking cardboard over for instance a PET-bottle was made. With the drinking } \\
\text { cardboard, you will always end up incinerating the cap and liner. With a PET } \\
\text { bottle with PP cap this would not be the case. }\end{array}$ & PRC1 & $\begin{array}{l}\text { could work, but not with neoprene. Clear } \\
\text { understanding of most of the issues in the } \\
\text { recycling chain of drinking cardboard, } \\
\text { however recyclers will not be to apply with } \\
\text { the usage of neoprene as this might end up in } \\
\text { the plastic recycling and block extrusion lines } \\
\text { or influence the quality of the recyclate. }\end{array}$ & $\begin{array}{l}\text { could work, not with } \\
\text { neoprene, clear } \\
\text { understanding of most issues, } \\
\text { not be happy, not clearly } \\
\text { explained }\end{array}$ & A \\
\hline 50 & $\begin{array}{l}\text { OVERALL: Not best idea but most developed. For group B there is good } \\
\text { cohesion, so this concept would have a high score. Goed te recyclen materialen, } \\
\text { prima maar niet exceptioneel [good recyclability but not exceptional] } \\
\text { SPECIFIC: } 1 . x .2 . x\end{array}$ & PRC2 & $\begin{array}{l}\text { Not best idea but most developed. There is } \\
\text { good cohesion, so this concept would have a } \\
\text { high score }\end{array}$ & $\begin{array}{l}\text { not best, most developed, } \\
\text { good cohesion, high score, } \\
\text { good to recycle, not } \\
\text { exceptional }\end{array}$ & B \\
\hline 51 & $\begin{array}{l}\text { OVERALL: Will never be a drinking carton again. Concept A does not have a } \\
\text { normal closure, and this is limiting cohesion. Jammer van het neopreen, } \\
\text { paperboard laminaat is redelijk te recyclen [Unfortunate choice for neoprene, } \\
\text { paperboard laminate is reasonably recyclable] } \\
\text { SPECIFIC: } 1 . x .2 . x\end{array}$ & PRC2 & $\begin{array}{l}\text { concept does not have a normal closure, and } \\
\text { this is limiting cohesion. Too bad for the } \\
\text { neoprene closure, however paperboard is } \\
\text { reasonable recyclable }\end{array}$ & $\begin{array}{l}\text { never be, limiting, too bad, } \\
\text { reasonably recyclable }\end{array}$ & A \\
\hline
\end{tabular}


Table A2. Cont.

\begin{tabular}{|c|c|c|c|c|c|}
\hline Quote No. & Complete Comment and Color & Initials Perspective & Quotes (Derived from the Comments) & $\begin{array}{l}\text { Terminology (Verbs, Nouns, } \\
\text { Adjectives) }\end{array}$ & Design \\
\hline 52 & $\begin{array}{l}\text { OVERALL: too many small objects. Concept D is too complicated and therefore } \\
\text { lacks cohesion. Te veel verschillende materialen, losse delen. Op deze manier } \\
\text { worden doppen niet gerecycled (te klein). [Too many different materials, loose } \\
\text { parts. This way, the caps will not be recycled [they are too small)] } \\
\text { SPECIFIC: } 1 . x \text { 2.x }\end{array}$ & PRC2 & $\begin{array}{l}\text { Concept is to complicated and therefore lacks } \\
\text { cohesion. Cap will not be recycled }\end{array}$ & $\begin{array}{l}\text { to many objects, too } \\
\text { complicated, lacks cohesion }\end{array}$ & $\mathrm{D}$ \\
\hline 53 & $\begin{array}{l}\text { OVERALL: best idea but no report! Concept C would become the second but } \\
\text { there is no report. Zelfde materialen als } C \text { maar nu ook rPET toegepast! [Same } \\
\text { materials used as concept C, but now rPET is also applied!] } \\
\text { SPECIFIC: } 1 \text {. x 2. x }\end{array}$ & PRC2 & best idea, but there is not report & best idea, no report & C \\
\hline 54 & $\begin{array}{l}\text { OVERALL: Most recyclable. SPECIFIC: } 1 \text {. They have basic knowledge and do } \\
\text { not elaborate too much on it. } 2 \text {. They made a design change to the label that has } \\
\text { great influence on the recyclability of the other materials. }\end{array}$ & PRC3 & $\begin{array}{l}\text { most recyclable, they made a design change } \\
\text { to the label that has great influence on the } \\
\text { recyclability }\end{array}$ & $\begin{array}{l}\text { most recyclable, basic } \\
\text { knowledge, not elaborate too } \\
\text { much, great influence on } \\
\text { recyclability }\end{array}$ & B \\
\hline 55 & $\begin{array}{l}\text { OVERALL: Is recyclable, except the lid, which is not designed for recycling. } \\
\text { SPECIFIC: } 1 \text {. They have basic knowledge and do not elaborate too much on it. } 2 \text {. } \\
\text { They did not do much of a change to their initial idea. }\end{array}$ & PRC3 & $\begin{array}{l}\text { is recyclable, except the lid. They did not do } \\
\text { much of a change to their initial idea }\end{array}$ & $\begin{array}{l}\text { is recyclable, not designed for } \\
\text { recycling, basic knowledge, } \\
\text { not elaborate too much, do } \\
\text { not change }\end{array}$ & A \\
\hline 56 & $\begin{array}{l}\text { OVERALL: Is well recyclable, but it feels like a lucky shot. SPECIFIC: } 1 \text {. Very } \\
\text { limited information } 2 \text {. Very limited information }\end{array}$ & PRC3 & is well recyclable, but feels like a lucky shot & $\begin{array}{l}\text { feels like a lucky shot, very } \\
\text { limited information }\end{array}$ & C \\
\hline 57 & $\begin{array}{l}\text { OVERALL: Good idea, but the use of all the different materials makes the end } \\
\text { of life difficult. SPECIFIC: } 1 \text {. Very limited knowledge of the recycling processes. } \\
\text { 2. No evidence of any changes. }\end{array}$ & PRC3 & $\begin{array}{l}\text { Good idea, but the use of all the different } \\
\text { materials makes the end of life difficult. }\end{array}$ & $\begin{array}{l}\text { good idea, end of life difficult, } \\
\text { very limited knowledge, no } \\
\text { evidence }\end{array}$ & $\mathrm{D}$ \\
\hline
\end{tabular}




\section{Appendix C}

Table A3. Questions derived from the original learning objectives.

\begin{tabular}{cc}
\hline Life cycle analysis (LCA) \\
\hline 1.1 & Have the students consistently applied the terminology of lifecycle assessment in the poster and the report? \\
1.2 & Are the outcomes of the LCA tool used to evaluate different kinds of packaging? \\
1.3 & How did the results of the LCA tool influence the design process, and the final design? \\
\hline Consumer purchase behavior (CPB) \\
\hline 2.1 & How well do the students show understanding of the expected behavior of consumers regarding sustainable purchasing? \\
2.2 & How did consumer purchasing behavior, regarding sustainability, influence the final design? \\
\hline Recycling behavior (RB) \\
\hline 3.1 & How well do the students show understanding of the expected behavior of consumers regarding recycling? \\
\hline 3.2 & How did consumer recycling behavior influence the final design? \\
\hline Plastic Recycling chain (PRC) \\
\hline 4.1 & How well do the students show understanding of the recycling process? \\
\hline How did the plastic recycling chain influence the final design? \\
\hline 5.2 & Do the students provide an overview of the choices, considerations, criteria, and trade-offs made during the design process? \\
\hline
\end{tabular}




\section{References}

1. World Commission on Environment and Development. Our Common Future; Oxford University Press: Oxford, UK, 1987.

2. United Nations General Assembly. World Summit Outcome, Resolution A/60/1; United Nations General Assembly: New York, NY, USA, 2005.

3. De Koeijer, B.; De Lange, J.; Wever, R. Desired, Perceived, and Achieved Sustainability: Trade-Offs in Strategic and Operational Packaging Development. Sustainability 2017, 9, 1923. [CrossRef]

4. Peck, T. Bottle Deposit Charge Needed to Save Oceans from Plastic Waste, Says MPs. Available online: https://www.independent.co.uk/news/uk/politics/plastic-pollution-oceans-waste-bottle-depositcharge-mary-creagh-a8123366.html (accessed on 22 December 2017).

5. Gabbatiss, J. Tesco to Ban Non-Recyclable Plastic Packaging by 2019. Available online: https: / /www.independent.co.uk/news/business/tesco-ban-non-recyclable-plastic-packaging-2019single-use-bags-a8365976.html (accessed on 23 May 2018).

6. Ten Klooster, R. Packaging Design: A Methodical Development and Simulation of the Design Process; Delft University of Technology: Delft, The Netherlands, 2002.

7. Bramklev, C. Towards Integrated Product and Package Development. Ph.D. Thesis, Lund University, Lund, Sweden, 2007.

8. Lutters, D.; Ten Klooster, R. Functional requirement specification in the packaging development chain. CIRP Ann. Manuf. Technol. 2008, 57, 145-148. [CrossRef]

9. Selke, S.E.M. Green packaging. In Green Technologies in Food Production and Processing; Boye, J.I., Arcand, Y., Eds.; Springer: New York, NY, USA, 2012; pp. 443-468.

10. Ellen MacArthur Foundation. Towards the Circular Economy; Ellen MacArthur Foundation Publishing: Cowes, UK, 2012; Volume 1.

11. McDonough, W.; Braungart, M. Cradle to Cradle: Remaking the Way We Make Things; North Point Press: New York, NY, USA, 2002.

12. McDonough, W.; Braungart, M. The Upcycle: Beyond Sustainability—Designing for Abundance; North Point Press: New York, NY, USA, 2013.

13. Byggeth, S.; Hochschorner, E. Handling trade-offs in Ecodesign tools for sustainable product development and procurement. J. Clean. Prod. 2006, 14, 1420-1430. [CrossRef]

14. Fitzgerald, D.P.; Herrmann, J.W.; Schmidt, L.C. A Conceptual Design Tool for Resolving Conflicts Between Product Functionality and Environmental Impact. J. Mech. Des. 2010, 132, 091006. [CrossRef]

15. Lofthouse, V. Ecodesign tools for designers: Defining the requirements. J. Clean. Prod. 2006, 14, $1386-1395$. [CrossRef]

16. Blumenfeld, P.; Soloway, E.; Marx, R.; Krajcik, J.; Guzdial, M.; Palincsar, A. Motivating project-based learning: Sustaining the doing, supporting the learning. Educ. Psychol. 1991, 26, 369-398. [CrossRef]

17. Jensen, B.B.; Schnack, K. The Action Competence Approach in Environmental Education. Environ. Educ. Res. 1997, 3, 163-178. [CrossRef]

18. Lewis, H. Designing for Sustainability. In Packaging for Sustainability; Verghese, K., Lewis, H., Fitzpatrick, L., Eds.; Springer: London, UK, 2012; pp. 41-106.

19. Jedlicka, W.; Amel, E.L.; Baumeister, D. Packaging Sustainability: Tools, Systems and Strategies for Innovative Package Design; Wiley: New York, NY, USA, 2008.

20. Lewis, H.; Verghese, K.; Fitzpatrick, L. Evaluating the sustainability impacts of packaging: The plastic carry bag dilemma. Packag. Technol. Sci. 2010, 23, 145-160. [CrossRef]

21. De Lange, J.; Oude Luttikhuis, E.; Ten Klooster, R.; Lutters, E. Towards integrating sustainability in the development of product/packaging combinations. In Proceedings of the 23rd CIRP Design Conference, Bochum, Germany, 11-13 March 2013; pp. 855-864.

22. Nordin, N.; Selke, S. Social aspect of sustainable packaging. Packag. Technol. Sci. 2010, 23, 317-326. [CrossRef]

23. Mulder-Nijkamp, M.; De Koeijer, B.; Torn, I.A.R. Implementing Sustainability Considerations in Packaging Design Curricula. In Proceedings of the 21st IAPRI World Conference on Packaging, Zhuhai, China, 19-22 June 2018; pp. 834-841.

24. Cross, N. Designerly ways of knowing. Des. Stud. 1982, 3, 221-227. [CrossRef] 
25. Buijs, J. Modelling Product Innovation Processes, from Linear Logic to Circular Chaos. Creat. Innov. Manag. 2003, 12, 76-93. [CrossRef]

26. Pahl, G.; Beitz, W.; Feldhusen, J.; Grote, K.-H. Engineering Design: A Systematic Approach, 3rd ed.; Springer: London, UK, 2007.

27. Dorst, K. The core of 'design thinking'and its application. Des. Stud. 2011, 32, 521-532. [CrossRef]

28. Deutz, P.; McGuire, M.; Neighbour, G. Eco-design practice in the context of a structured design process: An interdisciplinary empirical study of UK manufacturers. J. Clean. Prod. 2013, 39, 117-128. [CrossRef]

29. Wever, R.; Vogtländer, J. Design for the Value of Sustainability. In Handbook of Ethics, Values, and Technological Design; Van den Hoven, J., Vermaas, P.E., Van de Poel, I., Eds.; Springer: Dordrecht, The Netherlands, 2014; pp. 513-549.

30. Svanes, E.; Vold, M.; Møller, H.; Pettersen, M.K.; Larsen, H.; Hanssen, O.J. Sustainable Packaging Design: A Holistic Methodology for Packaging Design. Packag. Technol. Sci. 2010, 23, 161-175. [CrossRef]

31. Oude Luttikhuis, E.J.; De Lange, J.; Lutters, E.; Ten Klooster, R. Using actor networks in decision making during content-packaging development. Procedia CIRP 2014, 15, 419-424. [CrossRef]

32. De Koeijer, B.; Wever, R.; Henseler, J. Realizing Product-Packaging Combinations in Circular Systems: Shaping the Research Agenda. Packag. Technol. Sci. 2017, 30, 443-460. [CrossRef]

33. Thomas, J.W. A review of Research on Project Based Learning; The Autodesk Foundation: San Rafael, CA, USA, 2000.

34. Bloom, B.S. Taxonomy of Educational Objectives, Volume 1: Cognitive Domain; McKay: New York, NY, USA, 1956; pp. 20-24.

35. Cannon, H.M.; Feinstein, A.H.; Friesen, D.P. Managing complexity: Applying the conscious-competence model to experiential learning. Dev. Bus. Simul. Exp. Learn. 2010, 37, 172-182.

36. De Medeiros, J.F.; Ribeiro, J.L.D.; Cortimiglia, M.N. Success factors for environmentally sustainable product innovation: A systematic literature review. J. Clean. Prod. 2014, 65, 76-86. [CrossRef]

37. García-Arca, J.; Trinidad González-Portela Garrido, A.; Carlos Prado-Prado, J. “Sustainable Packaging Logistics". The link between Sustainability and Competitiveness in Supply Chains. Sustainability 2017, 9, 1098. [CrossRef]

38. Johansson, G. Success factors for integration of ecodesign in product development: A review of state of the art. Environ. Manag. Health 2002, 13, 98-107. [CrossRef]

39. Boks, C. The soft side of ecodesign. J. Clean. Prod. 2006, 14, 1346-1356. [CrossRef]

40. Hallstedt, S.I.; Thompson, A.W.; Lindahl, P. Key elements for implementing a strategic sustainability perspective in the product innovation process. J. Clean. Prod. 2013, 51, 277-288. [CrossRef]

41. Journeault, M.; De Rongé, Y.; Henri, J.-F. Levers of eco-control and competitive environmental strategy. Br. Account. Rev. 2016, 48, 316-340. [CrossRef]

42. Kärnä, J.; Hansen, E.; Juslin, H. Social responsibility in environmental marketing planning. Eur. J. Mark. 2003, 37, 848-871. [CrossRef]

43. Miles, M.P.; Covin, J.G. Environmental Marketing: A Source of Reputational, Competitive, and Financial Advantage. J. Bus. Ethics 2000, 23, 299-311. [CrossRef]

44. Munilla, L.S.; Miles, M.P. The Corporate Social Responsibility Continuum as a Component of Stakeholder Theory. Bus. Soc. Rev. 2005, 110, 371-387. [CrossRef]

45. Storaker, A.; Wever, R.; Dewulf, K.; Blankenburg, D. Sustainability in front-end innovation at design agencies. In Proceedings of the 8th International Symposium on Environmentally Conscious Design and Inverse Manufacturing, Jeju Island, Korea, 4-8 December 2013.

46. Van Hemel, C.; Cramer, J. Barriers and stimuli for ecodesign in SMEs. J. Clean. Prod. 2002, 10, 439-453. [CrossRef]

47. Edwards, M. An Integral Metatheory for Organisational Sustainability: Living with a crowded bottom line in chaotic times. In Business Sustainability I: Management, Technology and Learning for Individuals, Organisations and Society in Turbulent Environments; Putnik, G.D., Ávila, P., Eds.; School of Engineering, University of Minho: Guimarães, Portugal, 2010; pp. 1-13.

48. Jansson, J.; Nilsson, J.; Modig, F.; Hed Vall, G. Commitment to Sustainability in Small and Medium-Sized Enterprises: The Influence of Strategic Orientations and Management Values. Bus. Strat. Environ. 2017, 26, 69-83. [CrossRef] 
49. Martinez, V.G.; English, S. Why designers won't save the World. In Proceedings of the 11th European Academy of Design Conference, Boulonge-Billancourt, France, 22-24 April 2015.

50. Petala, E.; Wever, R.; Dutilh, C.; Brezet, H. The role of new product development briefs in implementing sustainability: A case study. J. Eng. Technol. Manag. 2010, 27, 172-182. [CrossRef]

(C) 2018 by the authors. Licensee MDPI, Basel, Switzerland. This article is an open access article distributed under the terms and conditions of the Creative Commons Attribution (CC BY) license (http:/ / creativecommons.org/licenses/by/4.0/). 